\title{
Discussion on Urban Epidemic Prevention and Control in Chang 'an City in Tang Dynasty
}

Yile Chen, Faculty Of Humanities And Arts, Macau University of Science And Technology, Macau,China

\begin{abstract}
Chinese cities have a history of at least five thousand years, and the city of Chang'an in the Tang Dynasty is a milestone. The planning and design of Chang'an City represented the most advanced level in the world at that time and laid the foundation for the design of China's capital city. With the global outbreak of the new crown virus COVID-19, it is even more necessary to enter the "post-epidemic era" for urban epidemic prevention and governance measures. In the history of the Tang Dynasty, there were 49 plague outbreaks, but they still created prosperous situations such as the "Excellent Governance during the Zhenguan Times" and "Flourishment Age of Kaiyuan Era". This article analyzes and explores the urban epidemic prevention and governance system of Tang Chang'an City from six aspects, including the site selection, water supply and drainage system, medical isolation facilities, Li-Fang walled ward management system, landscaping, and mainstream medical ideological guidance, and summarizes previous experience. Provide reference for follow-up modern urban epidemic prevention and management.
\end{abstract}

\section{Keywords}

Tang Chang'an City, urban epidemic prevention and control,Lifang system, rain and sewage diversion, curfew

\section{Introduction}

Chang'an in the Tang Dynasty was the oriental cultural center that appeared incomparably attractive to Japan, an island country lying to the east of China. Thousands of Japanese during their lifetime aspired to set foot on China's territory and visited Chang'an, considering it their greatest glory to study, seek enlightenment, sightsee, or witness the majesty of the Tang Dynasty's prosperity in Chang'an. The majority of scholars maintain that Japan dispatched at least 19 batches of envoys to China in those days, called "Envoys to the Tang Dynasty" in Manyoshu (a Japanese collection of poems), among whom were a great many Japanese celebrities of that time. The culture brought back by them from the Tang Dynasty to Japan encompassed architecture and urban planning. Heijo-kyo and Heian-kyo were two renowned cities of Japan entirely modeled after Chang'an in terms of layout. Heijo-kyo, which served as Japanese capital since $710 \mathrm{AD}$, was rectangular in shape with main roads passing through from east to west and north to south around every 500 meters. Suzakumon, the main gate of the imperial city Heijo-kyo, was virtually directly modeled after the Zhuque Gate of the Daming Palace in Chang'an. The planning and design of Chang'an reached the world's most advanced level at that time and laid the foundation for the design of China's capitals ever since. Summarizing the epidemic prevention and control system of the Tang Chang'an could provide references for future generations about how to live in the post-epidemic era. 


\section{Literature Review}

\subsection{Concept of urban epidemic prevention and control}

Broadly speaking, urban governance is a concept of urban space management, primarily related to issues such as urban positioning, planning, and sustainable development. It aims to achieve sustainable development in economy, society and ecology and obtain coordinated development within the entire region by combining the factors of production including capital, land, labor force, technology, information and knowledge. In a narrow sense, it refers to the process of interest integration during which government, private sector and non-profit organization, three main forms of organization that constitute an interdependent, multi-agent governance network, collaboratively tackle public issues, provide public services and promote public interest for the city based on equality and the governance mechanisms of participation, communication, consultation, and cooperation. Urban epidemic prevention and control appears essential in urban governance during the COVIOD-19 global pandemic. Local government has taken a number of measures and introduced various policies to fight against and contain the pandemic since its outbreak and to promote post-pandemic recovery and construction. Epidemic prevention and control refers to effective containment of epidemic diseases through coordination and cooperation among relevant departments under the leadership of the government.

\subsection{Methodology}

Research methods employed in this paper mainly include bibliometrics, historical analysis and case study. The first step was to statistically analyze existing academic papers on the Tang Chang'an that were published in the past eight years and identify their characteristics and research trends. The second step was to draw experience from related epidemic prevention and control measures taken by Chang'an through analysis of historical materials and in-depth discussion of the specific case.

\subsection{Existing research works on Tang Chang'an City}

In the present work, 150 documents published during 2013 and 2021 were selected from China National Knowledge Infrastructure (CNKI) by entering the keywords "Tang Chang'an City" (“唐长安城” in Chinese). The majority of their references, spanning nearly 70 years as shown by bibliometric visualization, are historical materials compiled and reprinted by Zhonghua Book Company in the late Qing Dynasty. The largest number of references come from 2009, when documents about the Tang Chang'an approximate 60 probably due to major events occurring in that year, including construction of the Tang Daming Palace National Heritage Park in Xi'an, and archaeological excavations at the site of Xing'an Gate by Xi'an task force for Tang Dynasty's cities sent by the Institute of Archaeology, Chinese Academy of Social Sciences. 2019 has seen the publication of a number of books and reports thanks to archaeological research. Additionally, Chang'an City, Daxing City, Giant Wild Goose Pagoda, the Sui and Tang Dynasties, archaeological excavation, and Chongde Fang ("Fang" meaning residential block) constitute the six key phrases that are most frequently mentioned. The above information is shown in Figure 1-5. 


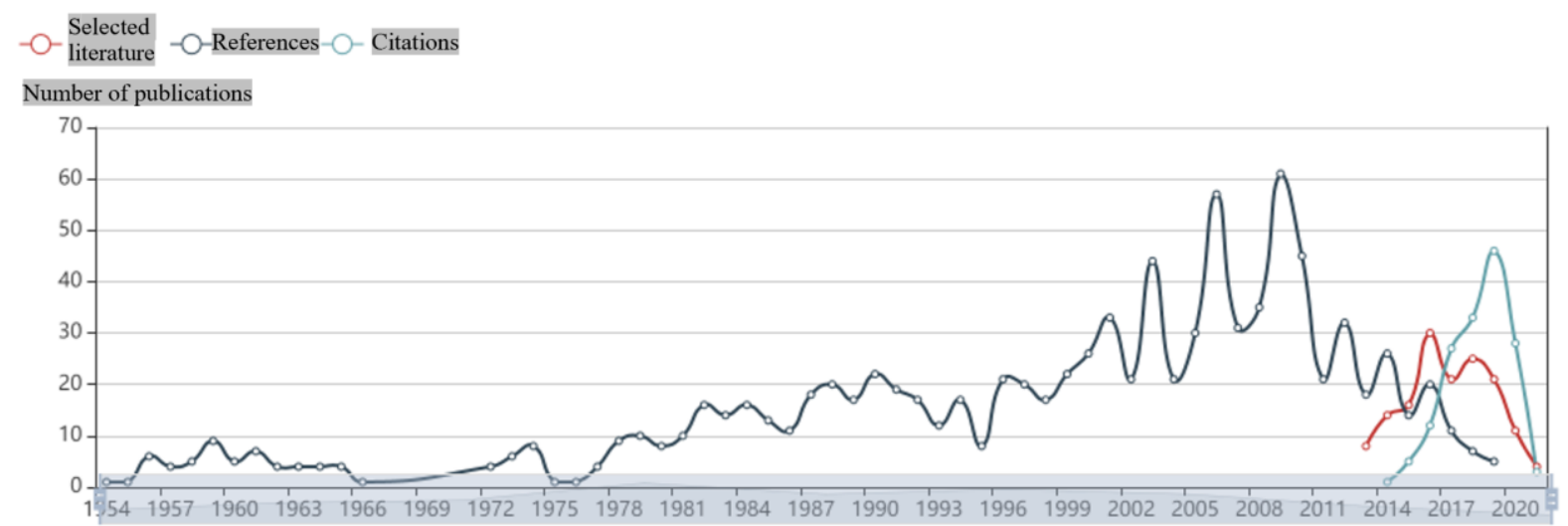

Figure 1. Overall trends in existing academic papers studying the Tang Chang'an. Source: exported from CNKI after generating images based on literature selected by the author.

\section{Types of resources}

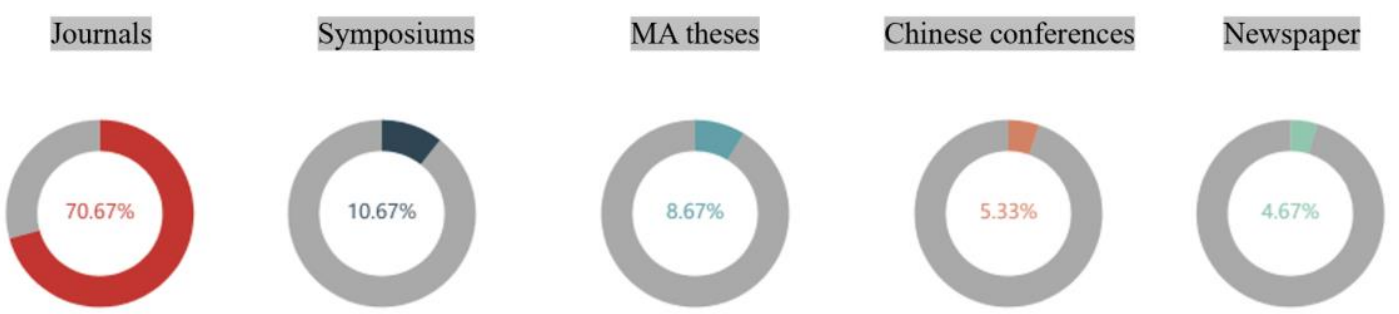

Figure 2. Distribution of the types of existing academic papers studying the Tang Chang'an. Source: exported from CNKI after generating images based on literature selected by the author.

\section{Distribution of disciplines}
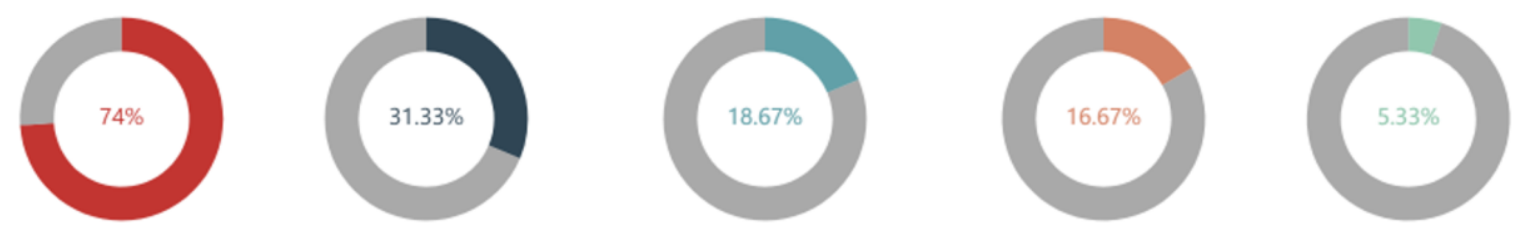

Figure 3. Distribution of the disciplines of existing academic papers studying the Tang Chang'an. Source: exported from CNKI after generating images based on literature selected by the author. 


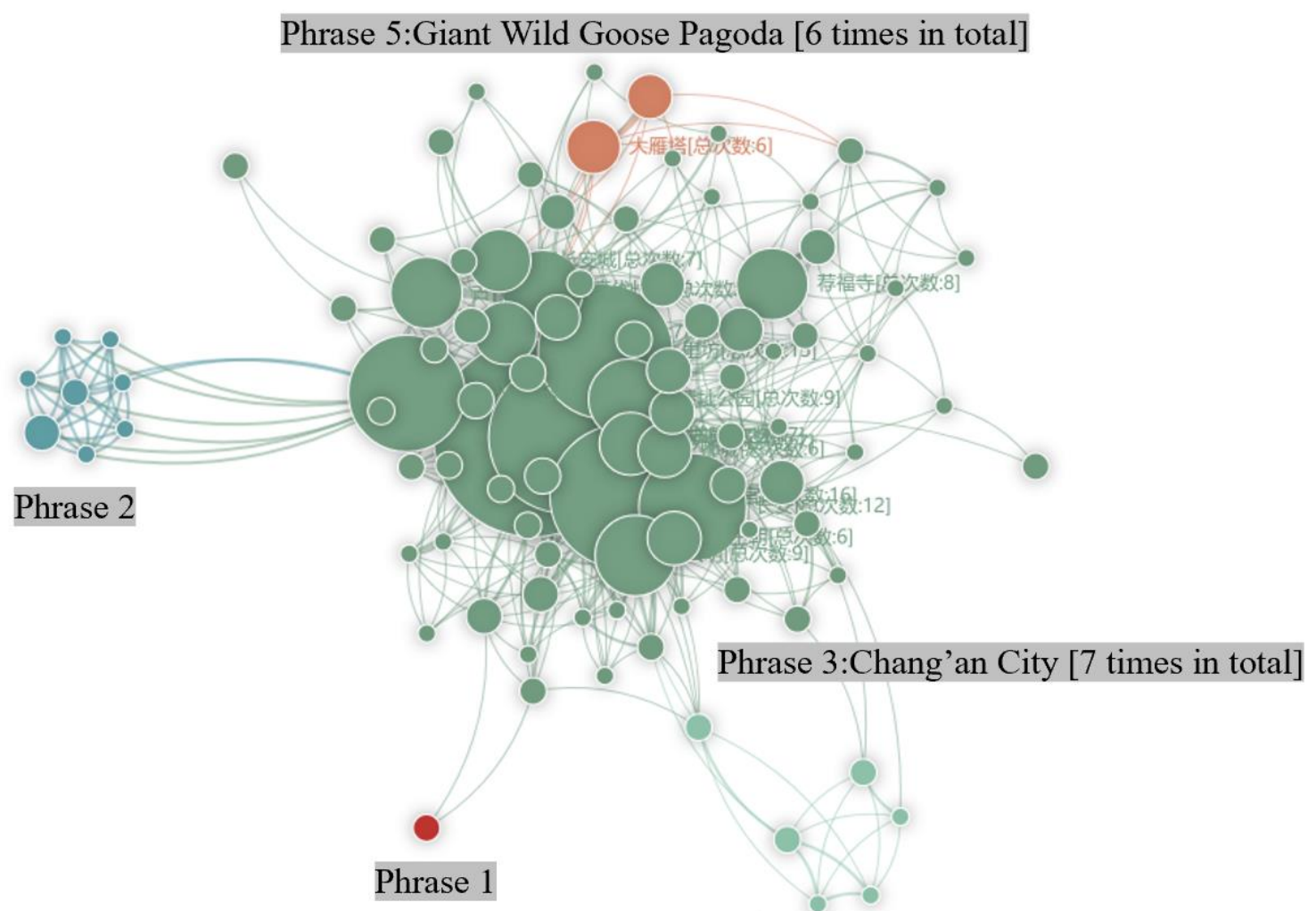

Phrase 4:Jianfu Temple [8 times in total]

Figure 4. Distribution of high-frequency phrases in existing academic papers studying the Tang Chang'an. Source: exported from CNKI after generating images based on literature selected by the author.

Distribution of sources (Publication name)

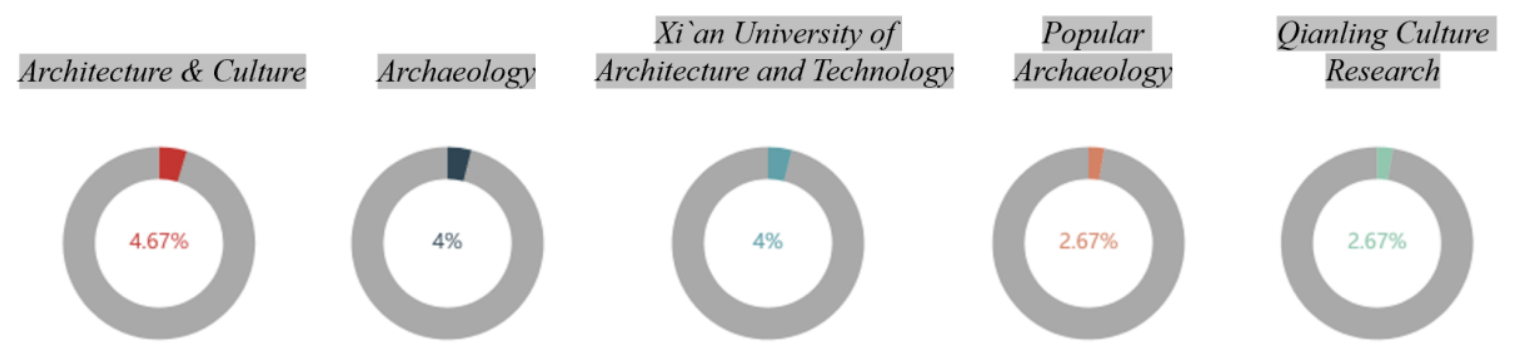

Figure 5. Distribution of the sources of existing academic papers studying the Tang Chang'an. Source: exported from CNKI after generating images based on literature selected by the author.

\section{Chang'an City in the Tang Dynasty}

\subsection{History of the Tang Chang'an}

Chang'an, originally called Daxing City (meaning "great prosperity") that was built in the 1st year of Kaihuang Period in the Sui Dynasty (581 AD), was renamed Chang'an when Li Yuan founded the Tang Dynasty, with administrative divisions consisting of Chang'an County and Wannian County under the 
jurisdiction of the Metropolitan Prefecture. It served as capital in the two dynasties and was the world's largest city at that time. Chang'an, known as Khumdan in foreign documents, was roughly situated on what is now the south bank of the Wei River close to Xi'an and Xianyang on Guanzhong Plain. Daxing City had a population of 250,000 (or 600,000 according to another source) during the Kaihuang Period of Emperor Wen in the Sui Dynasty, which increased to around 1 million during the reign of Empress Wu Zetian in the Tang Dynasty. Chang'an City in the two dynasties was considerably large in size. Actual measurement conducted by archaeologists proved that it took a rectangular shape which was $9,721 \mathrm{~m}$ long from east to west and 8,652 $\mathrm{m}$ wide from south to north with a circumference of $36.7 \mathrm{~km}$, covering a total area of $84 \mathrm{~km} 2$ and comprising three parts, namely the Outer City, the Palace City and the Imperial City. The Sui and Tang Chang'an was virtually six and seven times the size of Baghdad (capital of the Arab Empire) and Constantinople (today's Istanbul, capital of the Byzantine Empire) respectively, and six times of the Ming Chang'an. Daming Palace, the very place where most emperors in the Tang Dynasty lived and held court since Emperor Gaozong, occupied 320 hectares altogether, 3.5 times the size of the Palace Museum in Beijing, which indicated its grandeur and majesty. The city, in which every sector thrived, had a maximum population of 2 million in the municipal district and 1 million in the urban area.

Chang'an generally consisted of three parts, including the Palace City, the Imperial City and the Outer City. In the Outer City mainly stood residential areas, the East and the West Markets, while the Imperial City was the place where various government agencies of the court were established, and the Palace City encompassed Taiji Palace, Daming Palace and Xingqing Palace in which the emperor lived and administered state affairs. Chang'an was designed according to ancient Chinese cosmological schema, with Taiji Hall facing Polaris, symbolizing that the emperor ruled the state as ordered by the lord of heaven. The street outside Chengtian Gate (meaning "accepting heavenly ordered succession") in front of the Taiji Hall was called Chengtianmen Street. The straight axis serving as an extension line of state etiquette stretched from the Chengtian Gate to Zhuque Gate, namely the main entrance of the Imperial City, and to Mingde Gate, which was the Outer City's main entrance. Ceremonial buildings such as the Imperial Ancestral Temple and Shrine were symmetrically distributed on each side of the axis. Chang'an, as it were, remained a capital of cosmos and etiquette originally built to demonstrate the orthodoxy of the new dynasty. In World Metropolis Chang'an, the 47th episode of the program China History produced by China Movie Official Channel, Ning Xin, a professor from the School of History, Beijing Normal University, once remarked that the layout of the triple cities, even though already appearing prior the Sui and Tang Dynasties, was incomplete until Daxing City or Chang'an City was established, which could be substantiated by abundant materials from archaeological excavations. The Palace City, Imperial City, and Outer City constituted the triple cities that were strictly divided into different functional areas. Furthermore, Fang was residential blocks, the downtown area was used for commodity transactions, and the palace area was the office and living place for the emperor and his harem, all the three areas having walls. The Imperial City, lying in the center of Chang'an with its functions well defined and divisions in good order, abounded with government offices and exemplified the heyday of classical cities. 


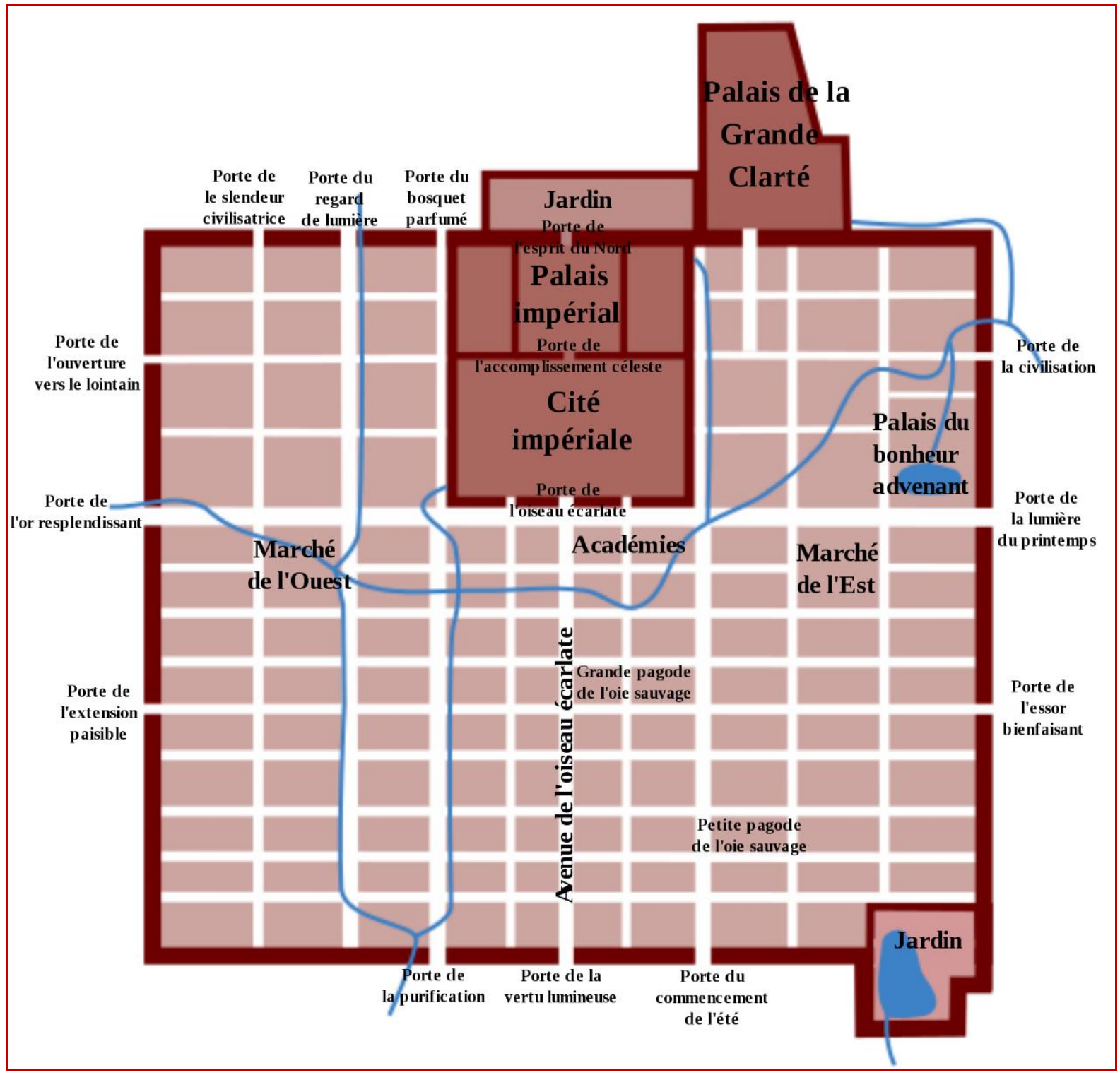

Figure 6. Ground plan of the Tang Chang'an.

Source:

https://zh.wikipedia.org/wiki/\%E5\%94\%90\%E9\%95\%BF\%E5\%AE\%89\%E5\%9F\%8E\#/media/File:Chang'a n_Tang_schema.svg. 


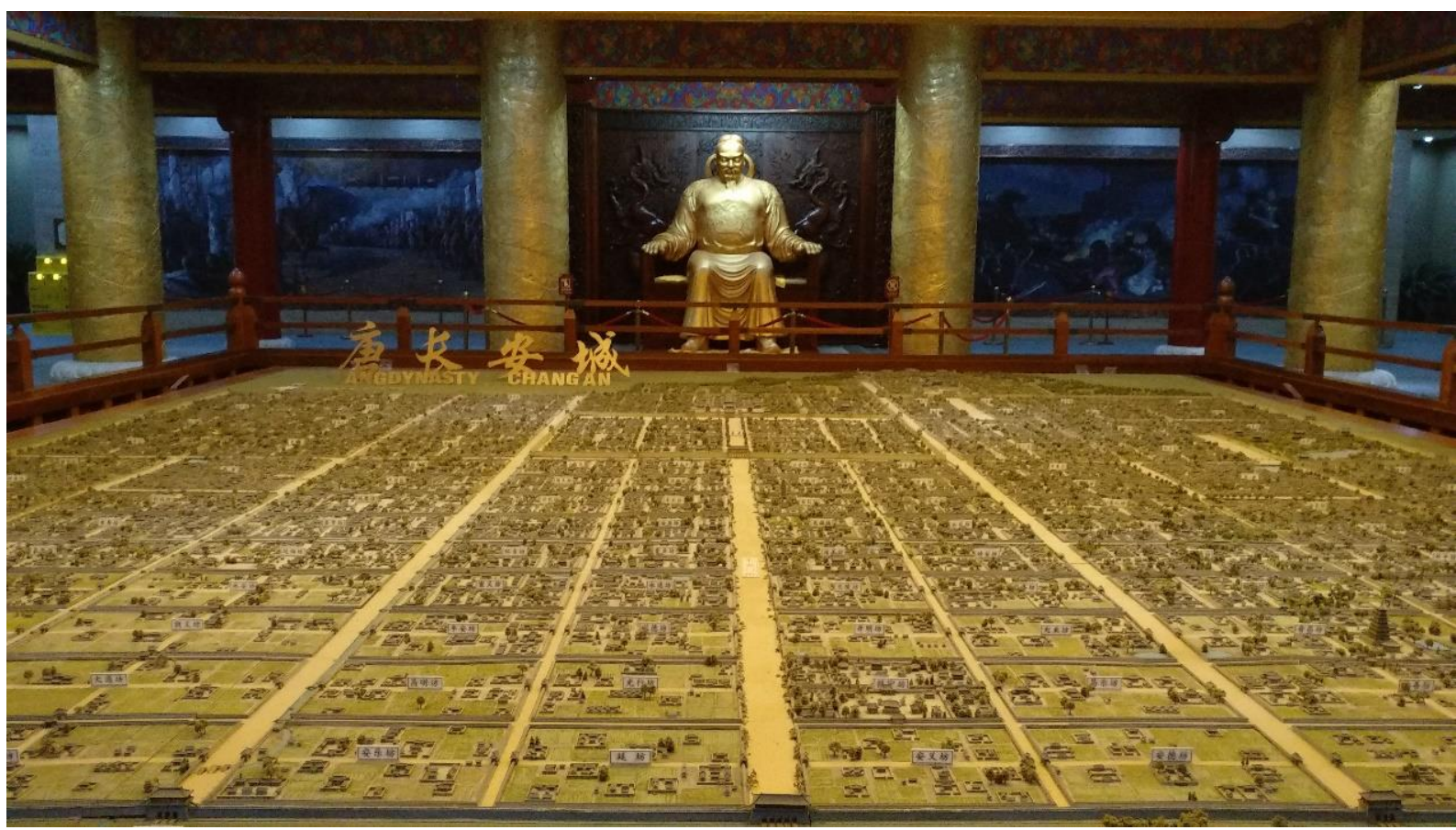

Figure 7. Sand table of the Tang Dynasty Chang'an in the Tang Paradise of Xi'an, Shanxi Province. Source: photographed by the author.

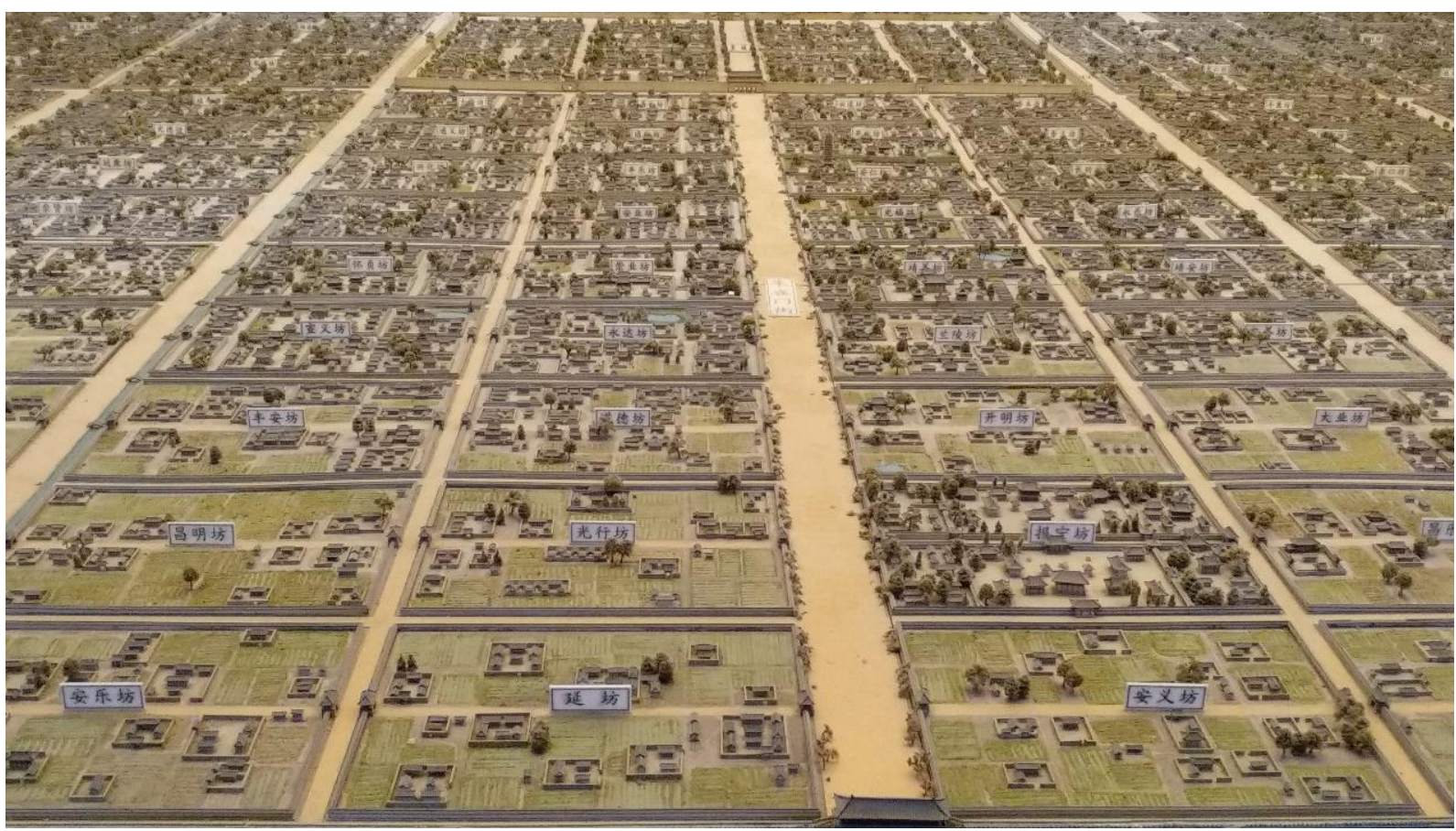

Figure 8. Sand table of the Tang Dynasty Chang'an in the Tang Paradise of Xi'an, Shanxi Province. Source: photographed by the author.

It was demolished at the end of the Tang Dynasty when the capital was moved to Luoyang, with its site remaining on a vast tract of land in today's Xi'an, Shanxi Province. In 1996, the site of Sui Daxing or Tang Chang'an was proclaimed by the State Council of PRC as one of the 4th batch of Key State Protected Historic Sites. The part of Xi'an City Wall standing until today was largely constructed during the Hongwu Period of the Ming Dynasty (1368-1378 AD) before fortified with bricks in the 4th year of the Longqing Period (1570 AD). Nowadays, the Sui and Tang Chang'an is buried 0.7-1 m underground in Xi'an, where its excavation sites are less than 30. Xi'an has built Daming Palace National Heritage Park, Tang Chang'an 
City Wall Heritage Park and Da Ci'en Temple Heritage Park to preserve the site of the Tang Chang'an. Among other remains of it in Xi'an are the Hanguang Gate Site Museum, Huangqiu Ruins, the exhibition area of the West Market ruins in Tang West Market Museum, ruins of the Chengtian Gate preserved in Lianhu Park, Giant Wild Goose Pagoda and Small Wild Goose Pagoda.

\subsection{Site selection of the Tang Chang'an City}

Yang Jian, a high-powered consort kin of the Northern Zhou Dynasty, proclaimed himself emperor and established the Sui Dynasty in 581 AD. Chang'an City was ravaged by war at that time, small in size and dilapidated. The residential blocks of officials and civilians were blended, while its drainage system was damaged due to the encroachment of the Wei River towards the south. Meanwhile, all water tasted salty and briny owing to massive groundwater extraction, proving not potable. In consequence, Yang Jian resolved to build and move to a new city.

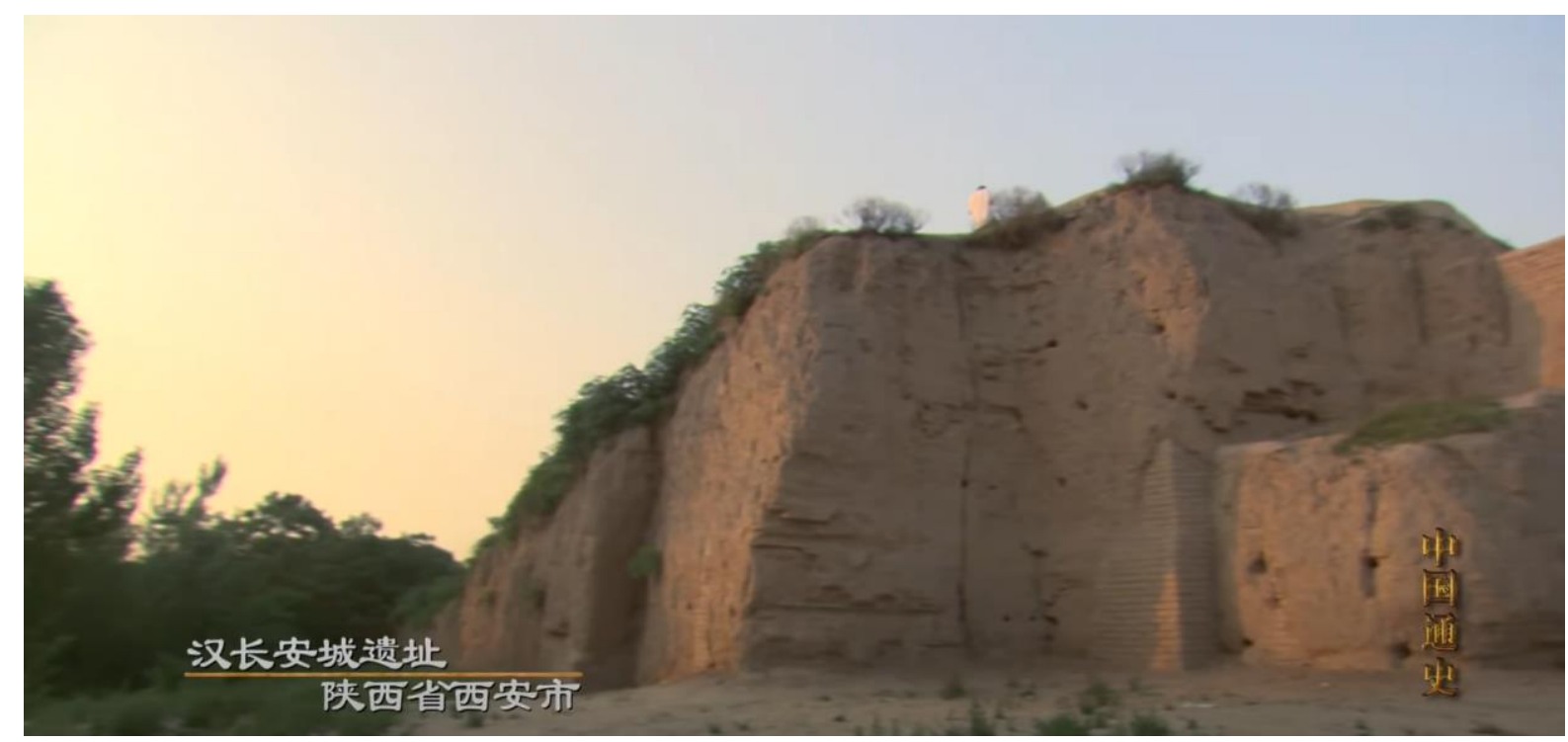

Figure 9. Site of Chang'an City in the Han Dynasty (today's Xi'an, Shanxi). Source: screenshot from World Metropolis Chang'an, the 47th episode of the program China History produced by China Movie Official Channel [EB/OL]. (2018, September 20) [cited on 2021, May 2]. https://www.youtube.com/watch?v=XORQzQd_Mj0.

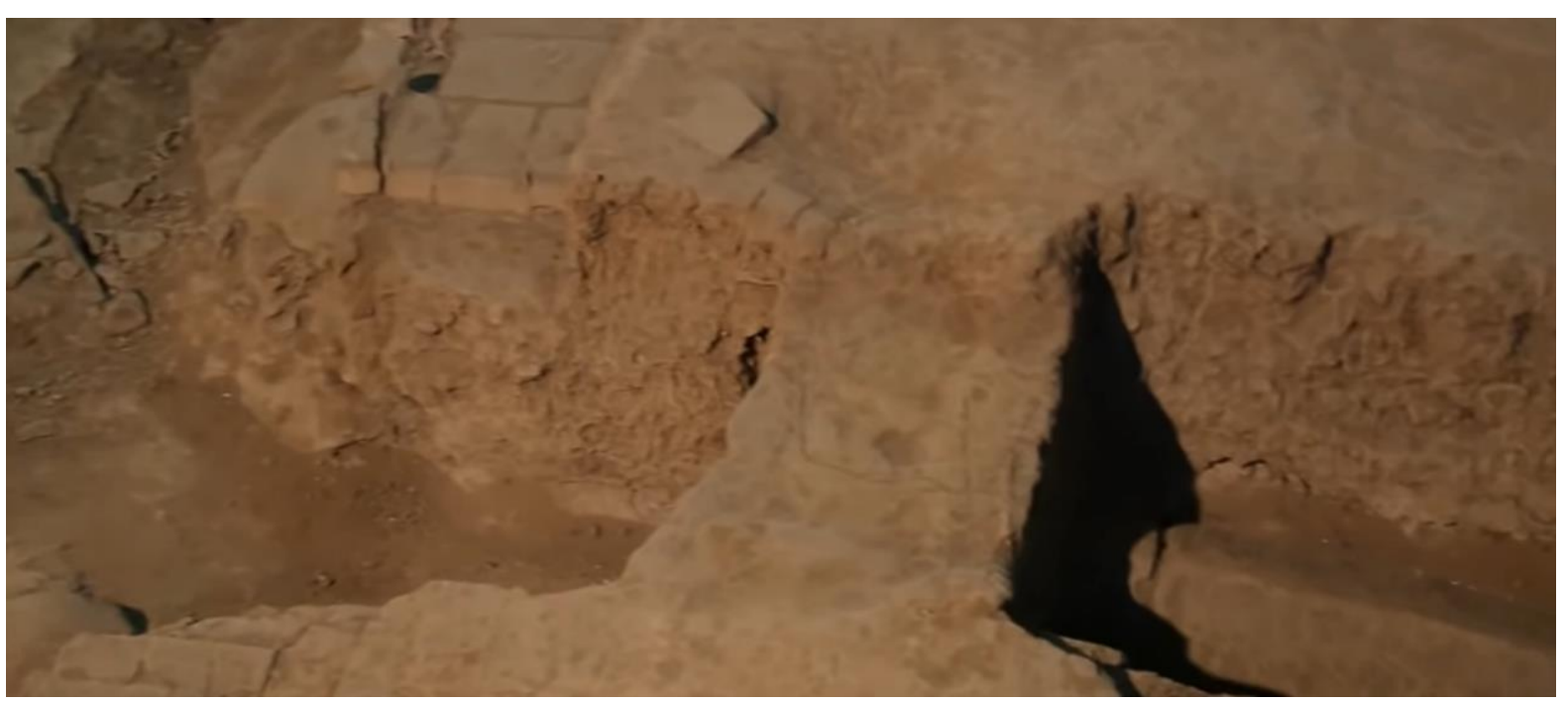

Figure 10. Excavations of the Chang'an site prove that its drainage system was damaged (today's Xi'an, Shanxi). Source: screenshot from World Metropolis Chang'an, the 47th episode of the program China 
History produced by China Movie Official Channel [EB/OL]. (2018, September 20) [cited on 2021, May 2]. https://www.youtube.com/watch?v=XORQzQd_Mj0.

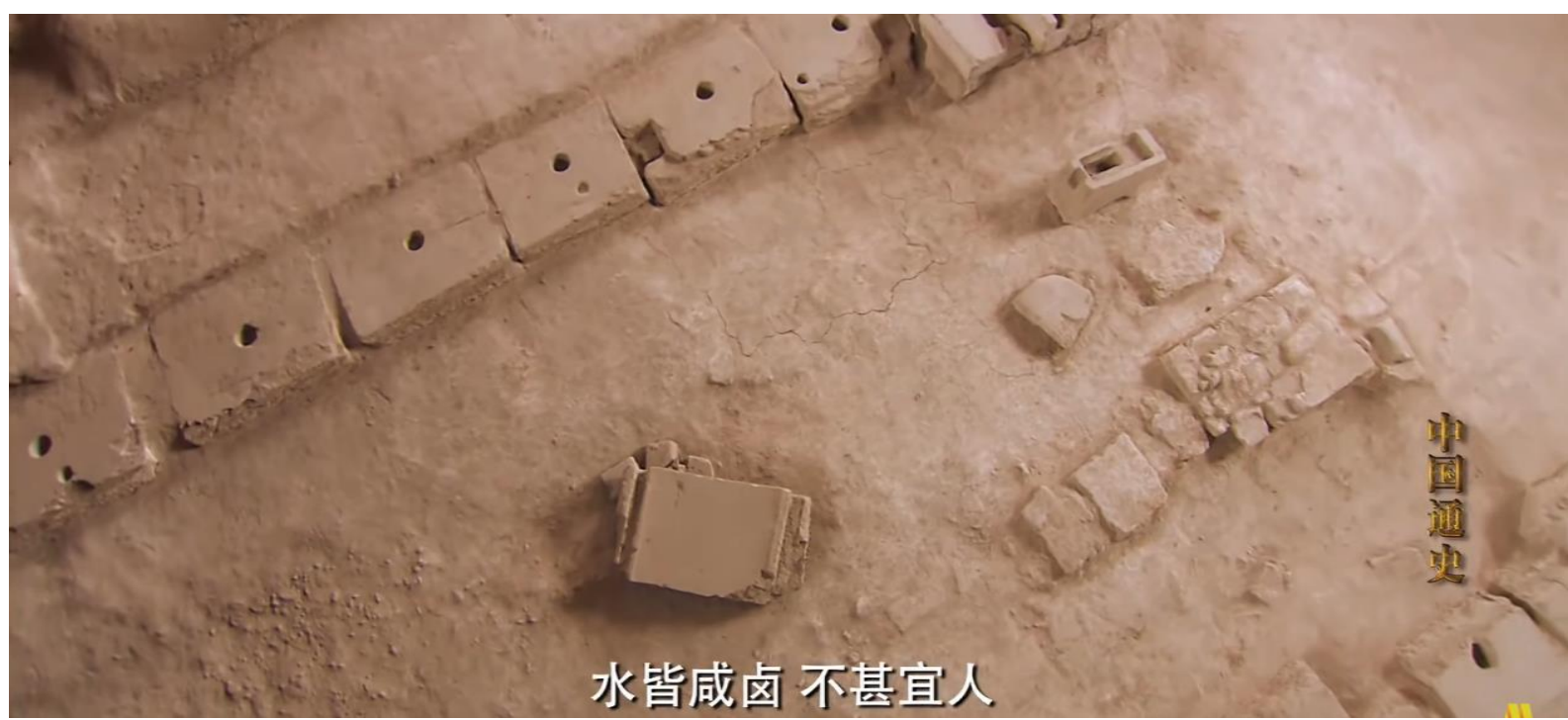

Figure 11. The aftermath of massive groundwater extraction (today's Xi'an, Shanxi). Source: screenshot from World Metropolis Chang'an, the 47th episode of the program China History produced by China Movie Official Channel [EB/OL]. (2018, September 20) [cited on 2021, May 2]. https://www.youtube.com/watch?v=XORQzQd_Mj0.

In World Metropolis Chang'an, the 47th episode of the program China History produced by China Movie Official Channel, Wang Jing, an associate professor from the School of History, Renmin University of China, claimed that building a new capital was complex rather than easy. Emperor Wen of the Sui Dynasty already held a discussion with Prime Minister Gao Jiong and Minister Su Wei at night. The next day, Yu Jicai, an official in charge of observing astronomical phenomena, reported that the conclusion he drew from nocturnal observation of the sky and reference to maps and records was quite consistent with the result of divination. Meanwhile, he persuaded the emperor that water had been contaminated in the Han Chang'an City, which could no longer serve as imperial residence. Therefore, Daxing City was constructed to be the capital on the Longshou Plain that lay to the south of the Han Dynasty's Great Wall and the southeast of the Han Chang'an.

Construction of the new city was specifically directed by Yuwen Kai, the then 27-year-old architect of reputation who was appointed as deputy supervisor (equivalent to today's deputy director of engineering) of the project to be fully responsible for its design and construction. He conducted field studies on the layout of those capitals prior to the Han Dynasty in order to assimilate the characteristics of their planning and layout, while traveling all over Chang'an to make site investigation. Eventually, a tract of open, valuable land with a good geomantic omen lying to the southeast of the Han Chang'an City and at the southern foot of the Longshou Plain was selected as the new site based on the theory of Feng Shui. Location of Chang'an met the site selection requirements of ancient capitals that they must be established "either at the foot of a huge mountain or in the vicinity of large rivers". Chang'an was a city that had easy access to the source of water while maintaining a proper distance from rivers. This place, where stood six hills with fertile soil, descended from the south to the north in topography. It nestled between today's Hongmiao Slope and Giant Wild Goose Pagoda at the east and west, bordering the Wei River to the north, the Chan River and Ba River to the east, the Feng River to the west and the Zhongnan Mountain to the south. The interior of Chang'an in topography descended from the southeast to northwest, allowing canal water channeled in from the southeast to naturally run through the whole city and flow out of it in northwest thanks to the fall of water and resulting potential energy. This extensive and scenic place, which boasted accessible land and water transportation and a favorable geographical 
location, proved ideal for founding a capital and outperformed other ancient cities in terms of water supply and drainage system.

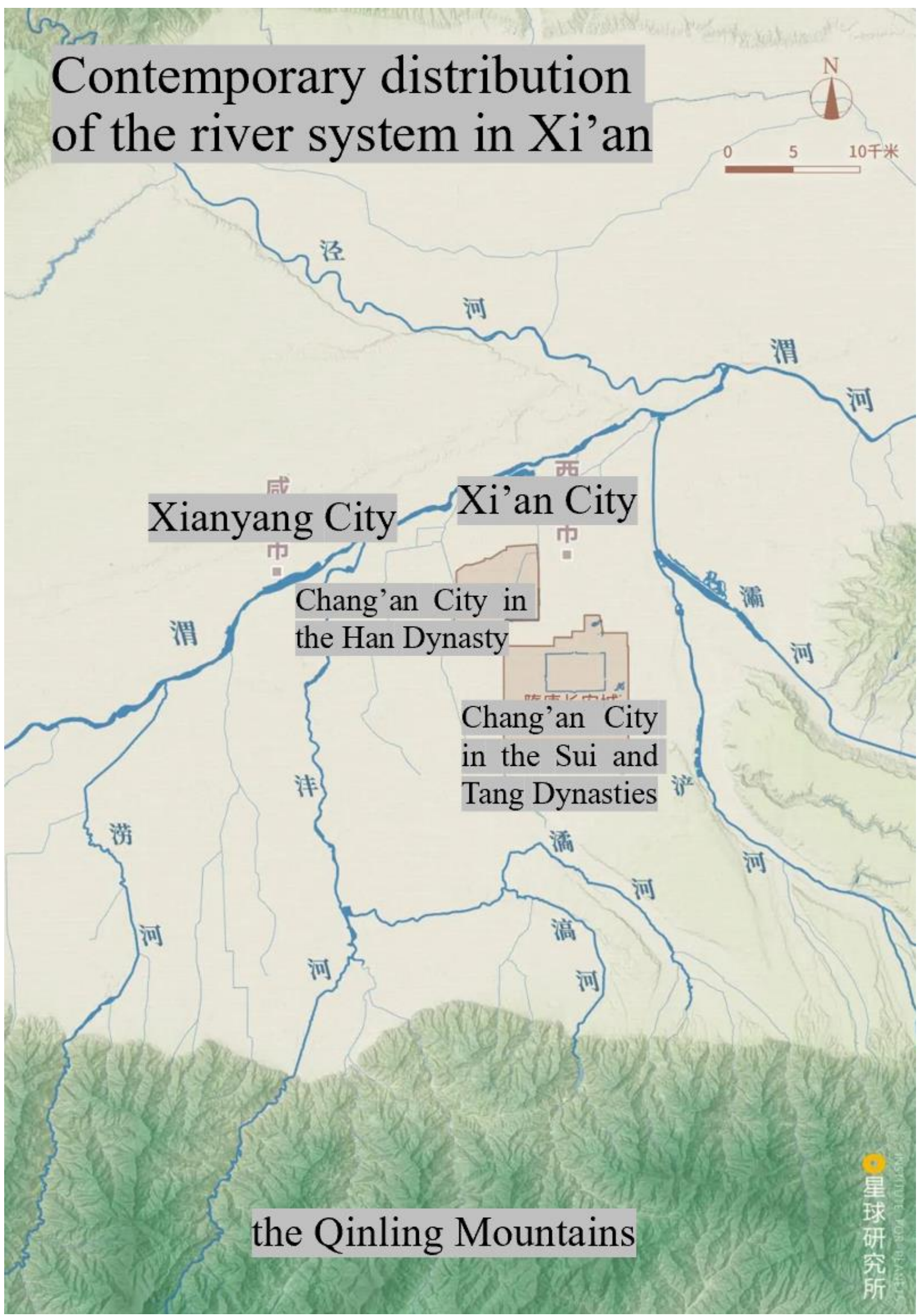

Figure 12. Schematic diagram of "eight rivers surrounding Chang'an". Source: WeChat official account of "Institute for Planets". 


\subsection{Historical records of plagues in the Tang Dynasty}

Historical records of plagues in the Tang Dynasty commenced in the 10th year of Zhenguan Period (636 $A D$ ) and terminated in the 2nd year of Dashun Period ( 891 AD), during which the outbreaks totaled 49 according to materials including the Old Book of Tang, New Book of Tang, Zizhi Tongjian (Comprehensive Mirror in Aid of Governance), Extensive Records of the Taiping Era and Tang Guo Shi Bu (Supplement to the History of the Tang Dynasty). Plagues occurred most frequently in particular during the Zhenguan Period, totaling 10 from the 1st year to the 22nd year and averaging once every two years, which caused great suffering. Leprosy was a highly infectious plague which attracted government attention due to its horrible symptoms that anyone contracting it would suffer hand and foot ulcers, anaphalantiasis and depressed nasal bridge.

Table 1. Some historical records of plagues in the Tang Dynasty. Source: compiled by the author based on historical materials.

\begin{tabular}{|c|c|c|c|}
\hline Year/time & Location of plague outbreak & Original record in historical material & Source \\
\hline $\begin{array}{c}\text { The 10th year of } \\
\text { Zhenguan Period (636 AD) }\end{array}$ & $\begin{array}{l}\text { Inside the Shanhai Pass and to the } \\
\text { east of the Yellow River }\end{array}$ & $\begin{array}{l}\text { A severe epidemic occurred inside the Shanhai } \\
\text { Pass and to the east of the Yellow River. }\end{array}$ & \\
\hline $\begin{array}{c}\text { The 15th year of } \\
\text { Zhenguan Period (641 AD) }\end{array}$ & $\begin{array}{c}\text { Zezhou (today's Jincheng City, Shanxi } \\
\text { Province) }\end{array}$ & Zezhou was stricken by an epidemic in March. & \\
\hline $\begin{array}{l}\text { The 16th year of } \\
\text { Zhenguan Period (642 AD) }\end{array}$ & $\begin{array}{c}\text { Guzhou (today's Yima City, Henan } \\
\text { Province), Jingzhou (Jingchuan } \\
\text { County, Gansu Province), Xuzhou, } \\
\text { Daizhou (Heze City, Shandong } \\
\text { Province) and Guozhou (Lingbao City, } \\
\text { Henan Province) }\end{array}$ & $\begin{array}{l}\text { In summer, an epidemic broke out in Guzhou, } \\
\text { Jingzhou, Xuzhou, Daizhou and Guozhou. }\end{array}$ & \\
\hline $\begin{array}{c}\text { The 17th year of } \\
\text { Zhenguan Period (643 AD) }\end{array}$ & Tanzhou, Haozhou and Luzhou & $\begin{array}{l}\text { In summer, an epidemic hit Tanzhou, Haozhou } \\
\text { and Luzhou. }\end{array}$ & \\
\hline $\begin{array}{l}\text { The 18th year of } \\
\text { Zhenguan Period (644 AD) }\end{array}$ & $\begin{array}{l}\text { Luzhou (today's Hefei City), Haozhou } \\
\text { (Fengyang County, Anhui Province), } \\
\text { Bazhou (Bazhou District, Bazhong } \\
\text { City, Sichuan Province), Leshanzhou } \\
\text { (around Hechi City, Guangxi Province) } \\
\text { and Chenzhou }\end{array}$ & $\begin{array}{l}\text { An epidemic occurred in Luzhou, Haozhou, } \\
\text { Bazhou, Leshanzhou and Chenzhou. }\end{array}$ & $\begin{array}{c}\text { The Old \& New } \\
\text { Book of Tang }\end{array}$ \\
\hline $\begin{array}{c}\text { The } 22 \text { nd year of } \\
\text { Zhenguan Period ( } 648 \text { AD) }\end{array}$ & $\begin{array}{l}\text { Qingzhou (today's Nanmaxiang, } \\
\text { Changshun County, Guizhou Province) }\end{array}$ & Qingzhou was hit by a severe epidemic. & \\
\hline $\begin{array}{l}\text { The 6th year of Yonghui } \\
\text { Period (655 AD) }\end{array}$ & Chuzhou (today's Huai'an) & $\begin{array}{c}\text { In March, Chuzhou experienced a severe } \\
\text { epidemic. }\end{array}$ & \\
\hline $\begin{array}{l}\text { The 1st year of Yongchun } \\
\text { Period (682 AD) }\end{array}$ & $\begin{array}{l}\text { Guanzhong (today's Xi'an, Baoji, } \\
\text { Xianyang, Weinan and Tongchuan) }\end{array}$ & $\begin{array}{l}\text { In June, the first rain in Guanzhong inundated } \\
\text { and damaged wheat seedlings, which was } \\
\text { aggravated by ensuing drought. Locusts in the } \\
\text { Capital Area, Qizhou and Longzhou virtually } \\
\text { ate up all of them. Since a great many people } \\
\text { contracted infectious diseases, roads were } \\
\text { piled with corpses. An edict issued by the }\end{array}$ & \\
\hline
\end{tabular}




\begin{tabular}{|c|c|c|c|}
\hline Year/time & Location of plague outbreak & Original record in historical material & Source \\
\hline & & court ordered local government to bury them. & \\
\hline $\begin{array}{l}\text { The 3rd year of Chuigong } \\
\text { Period } \\
\text { (687 AD) }\end{array}$ & $\begin{array}{l}\text { The region stretching from the capital } \\
\text { to Shandong }\end{array}$ & $\begin{array}{l}\text { It was in spring that an epidemic disease, } \\
\text { which occurred in the area stretching from the } \\
\text { capital to Shandong, caused a substantial } \\
\text { number of fatalities. }\end{array}$ & $\begin{array}{c}\text { Annals of } \\
\text { Emperor } \\
\text { Zhongzong in } \\
\text { the Old Book of } \\
\text { Tang }\end{array}$ \\
\hline $\begin{array}{l}\text { The 1st year of Jinglong } \\
\text { Period (707 AD) }\end{array}$ & Hebei & $\begin{array}{l}\text { In the summer of } 707 \mathrm{AD} \text {, thousands of people } \\
\text { died from an epidemic in the capital, } \\
\text { Shandong and Hebei. }\end{array}$ & $\begin{array}{l}\text { Treatises on the } \\
\text { Five Elements in } \\
\text { the New Book } \\
\text { of Tang }\end{array}$ \\
\hline $\begin{array}{l}\text { The 1st year of Baoying } \\
\text { Period (762 AD) }\end{array}$ & $\begin{array}{l}\text { Three cities in the Region of Wu } \\
\text { (Wuxing, Wujun and Danyang) }\end{array}$ & $\begin{array}{l}\text { A severe drought occurred in Wuxing, Wujun } \\
\text { and Danyang. People suffering starvation } \\
\text { practiced cannibalism. The next year saw the } \\
\text { outbreak of a major epidemic. Seven or eight } \\
\text { out of ten deceased, making residences in } \\
\text { cities deserted. Survivors was devoid of food, } \\
\text { whereas the dead had neither coffins nor } \\
\text { farewell funeral services. Generally, people } \\
\text { would eat the flesh and abandon the } \\
\text { remaining bones in the fields even though the } \\
\text { dead were their parents, wives or children. } \\
\text { Consequently, roads piled with bones } \\
\text { stretched two thousand miles, which had no } \\
\text { similar case in historical records since the } \\
\text { Spring and Autumn Period. }\end{array}$ & $\begin{array}{l}\text { Elegiac Address } \\
\text { to People Dying } \\
\text { from Starvation } \\
\text { on the Road }\end{array}$ \\
\hline
\end{tabular}

\begin{tabular}{|c|c|c|c|}
\hline $\begin{array}{l}\text { The 1st year of Guangde } \\
\text { Period during the reign of } \\
\text { Emperor Daizong } \\
\text { (763 AD) }\end{array}$ & East of the Yangtze River & $\begin{array}{l}\text { Over half of people died from a major } \\
\text { epidemic to the east of the Yangtze River. }\end{array}$ & $\begin{array}{l}\text { Elegiac Address } \\
\text { to People Dying } \\
\text { from Starvation } \\
\text { on the Road }\end{array}$ \\
\hline $\begin{array}{l}\text { The } 5 \text { th year of Zhenyuan } \\
\text { Period (789 AD) }\end{array}$ & $\begin{array}{l}\text { Huainan, eastern Zhejiang, western } \\
\text { Zhejiang and Fujian }\end{array}$ & $\begin{array}{l}\text { It was in that summer that Huainan, eastern } \\
\text { Zhejiang, western Zhejiang and Fujian were } \\
\text { stricken by a drought, which dried up most } \\
\text { wells and springs. People were thirsty and } \\
\text { exhausted and a great many died from an } \\
\text { epidemic. }\end{array}$ & $\begin{array}{c}\text { The Old \& New } \\
\text { Book of Tang }\end{array}$ \\
\hline $\begin{array}{c}\text { The 16th year of } \\
\text { Zhenyuan Period ( } 800 \text { AD) }\end{array}$ & $\begin{array}{c}\text { Guangli City (nowadays in the south } \\
\text { of Xiangcheng County, Henan } \\
\text { Province) }\end{array}$ & $\begin{array}{l}\text { It was increasingly sweltering. Han Quanyi } \\
\text { neglected to mollify soldiers who had been } \\
\text { stationed in a low-lying damp land for a long } \\
\text { time, which sparked disloyalty. On the Gengxu } \\
\text { Day in May, they engaged in a battle on the } \\
\text { Guangli Plain to the south of the Zhong River } \\
\text { with the army led by Wu Xiu and Wu }\end{array}$ & $\begin{array}{c}\text { Volume } 235 \text { of } \\
\text { Comprehensive } \\
\text { Mirror in Aid of } \\
\text { Governance }\end{array}$ \\
\hline
\end{tabular}




\begin{tabular}{|c|c|c|c|}
\hline Year/time & Location of plague outbreak & Original record in historical material & Source \\
\hline & & $\begin{array}{l}\text { Shaoyang, two military officers under the } \\
\text { commander of Wu Shaocheng, fighting with } \\
\text { weapons but ending up with a major defeat. } \\
\text { Pursued by Wu Xiu's army, Han Quanyi } \\
\text { retreated to defend Wulou (today's southwest } \\
\text { of Shangshui County, Henan Province). }\end{array}$ & \\
\hline $\begin{array}{c}\text { The 1st year of } \\
\text { Guangming Period (880 } \\
\text { AD) }\end{array}$ & $\begin{array}{c}\text { Xinzhou (today's Fuyang City, Anhui } \\
\text { Province) }\end{array}$ & $\begin{array}{l}\text { In the late spring of } 880 \text { AD (a lunar Gengzi } \\
\text { year), thieves in Xinzhou contracted virulent } \\
\text { epidemic diseases, resulting in a high fatality } \\
\text { rate. The masses were also attacked by the } \\
\text { epidemic. }\end{array}$ & $\begin{array}{c}\text { Annals of } \\
\text { Emperor Xizong } \\
\text { in the Old Book } \\
\text { of Tang }\end{array}$ \\
\hline
\end{tabular}

\subsection{Planning of epidemic prevention in the Tang Chang'an}

\subsubsection{Establishing medical institutions and Bing Fang (ward buildings)}

Local public medical institutions in the Tang Dynasty, which were initially established in the 3rd year of Zhenguan Period (629 AD), were staffed by one medical doctor and 10-20 medical students in each state except 30 medical students in Yongzhou, which had jurisdiction over Chang'an. They traveled around their respective regions to diagnose and treat patients. Records in the New Book of Tang demonstrates that central institutions of medical affairs in the Tang Dynasty mainly comprised three departments, namely the Bureau of Shangyao (an institution in charge of medications and pharmaceutical administration) in the Department of Dianzhong (an organ in charge of basic necessities of emperor's life), the Bureau of Yaocang in the Left Spring Quarters (secretariat of the heir apparent), and Office of Imperial Physicians in Taichang Temple. These institutions created a relatively scientific framework at the top level for the diagnosis and treatment of epidemic diseases, stockpiling of anti-epidemic drugs, and implementation of anti-epidemic activities, which effectively stemmed the spread of epidemic diseases.

During the outbreak of an epidemic, local medical institutions would collaborate with charities, such as monasteries, to contain the epidemic under the guidance of central institutions. Additionally, "Fang", specialized agencies initially established in the Tang Dynasty to succor patients, disabled people, beggars and paupers, was founded to control contagious diseases through quarantine and isolation. To accommodate the homeless, poor, and sick, temples set up "Beitian Yangbing Fang (Ward Buildings for Nursing and Rehabilitation)", and afterwards, public charitable ward buildings were established in the 22nd year of Kaiyuan Period during the reign of Emperor Xuanzong (734 AD). Juncao Fang, Jieting Fang, Yanshe Chu (literally meaning "kitchen in charge of banquets"), Bing Fang and Changxing Fang appeared in the Accounting Documentation of Dunhuang County during the Tianbao Period of Tang, confirming that ward buildings were established in each state during that period. The Tang Dynasty established specialized ward buildings to receive patients suffering from infectious diseases, which served the same purpose as public health centers and isolation sites built in the present. In Chang'an, those buildings were located in Buddhist temples in the vicinity of the two capitals. Patients of different gender were separately hospitalized, having access to medicine and food that were timely provided, which considerably contributed to disease prevention and control. 


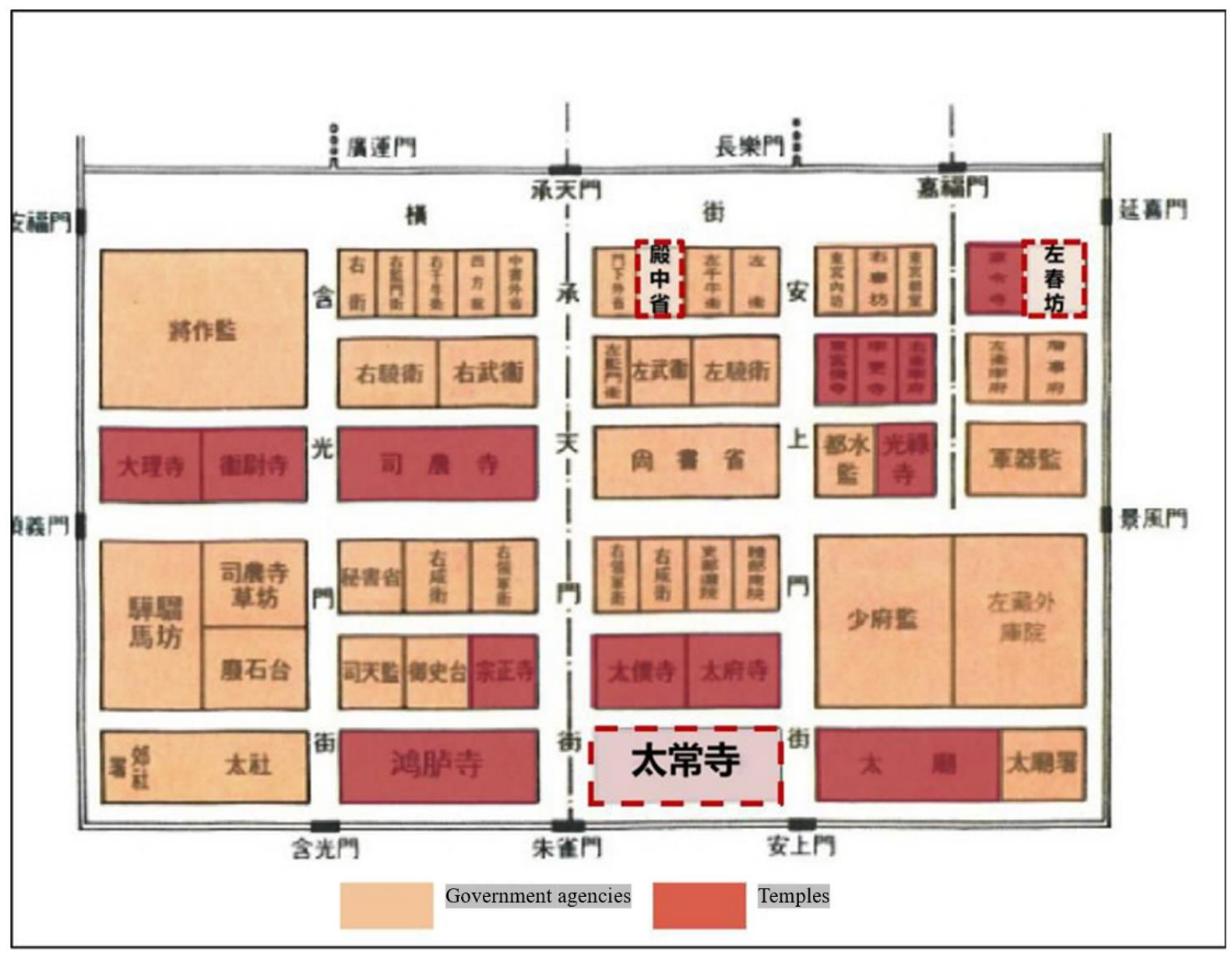

Figure 13. The imperial city of the Tang Chang'an. Source: Branch of Historical Cities, Research Institute of Xi'an City Planning \& Design.

\subsubsection{Ensuring the public health of urban water supply and drainage facilities}

The Tang Chang'an remained a populous city that normally had a population of 0.8-1 million, indicating that a sound sewage drainage system was indispensable. Yuwen Kai designed numerous water canals in Daxing City to address the needs for domestic water by diverting rivers and lakes into the city.

\section{(1) Components of the drainage system in the Tang Chang'an}

The Tang Chang'an, situated on the Guanzhong Plain with fertile soil, was steep and impregnable on all sides, backed by Qinling Mountains on the south and facing towards the Wei River on the north. It was surrounded by eight rivers, including the Jing, Wei, Hao, Feng, Chan, Jue, Ba and Lao Rivers, which supplied abundant water resources. To better utilize them, the Sui and Tang Dynasty channeled water from outside into the city by constructing water conservancy facilities such as the Qingming, Longshou, Yongan, Huang and Cao Canals. Water flowing into the city was stored in "water diversion weirs", special dams with outlets allowing residents to access water conveniently. Longshou Weir was the largest one in Chang'an City. Records of Chang'an City demonstrates that the water it retained came from the Chan River, which was directed into Longshou Canal and then divided into two tributaries on the Changle Slope (meaning "perpetual pleasure"), one running northward through the Wangchun Palace to the west city of Chang'an, and the other flowing into the Xingqing Pond. This weir was situated in "Matou Kong (literally meaning a control point shaped like a horse head)", a place which adjoined the West Market of Chang'an and abounded with shops, living quarters, residents and merchants, consuming a considerable amount of water. Among other large water diversion weirs were the Liangshan, Yongfu, and Liugong Weirs, all of 
Yile, C.

which lay in downtown areas. They raised water levels of the rivers, removed impurities, and kept the canal water in a circular, self-cleaning process, which satisfied the living needs of urban residents.

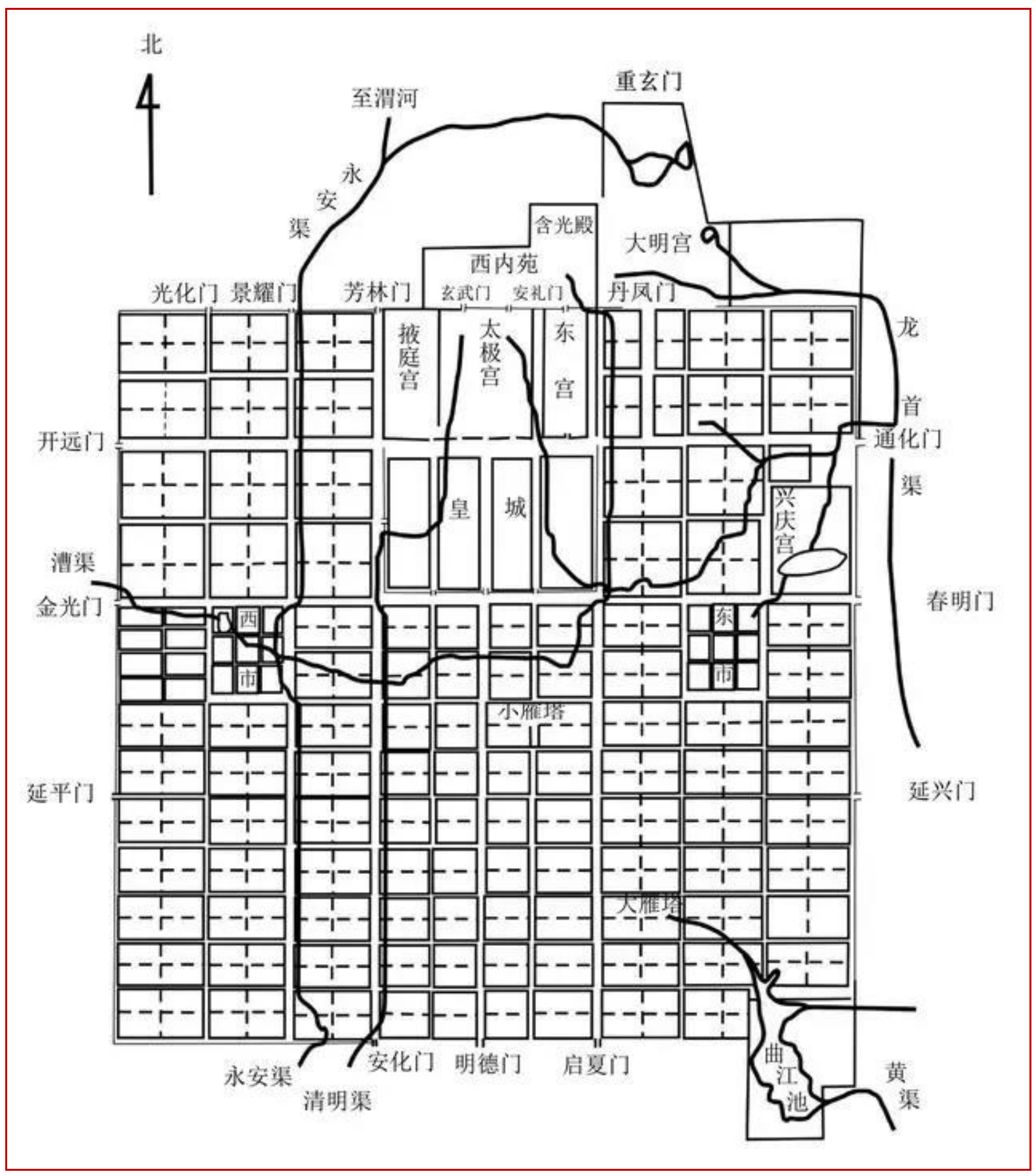

Figure 14. Schematic diagram of the drainage network in Chang'an. Source: Xu hong, The Drainage System of Ancient Chinese Cities. China Cultural Relics News, 2012, August 3, the 5th edition. 


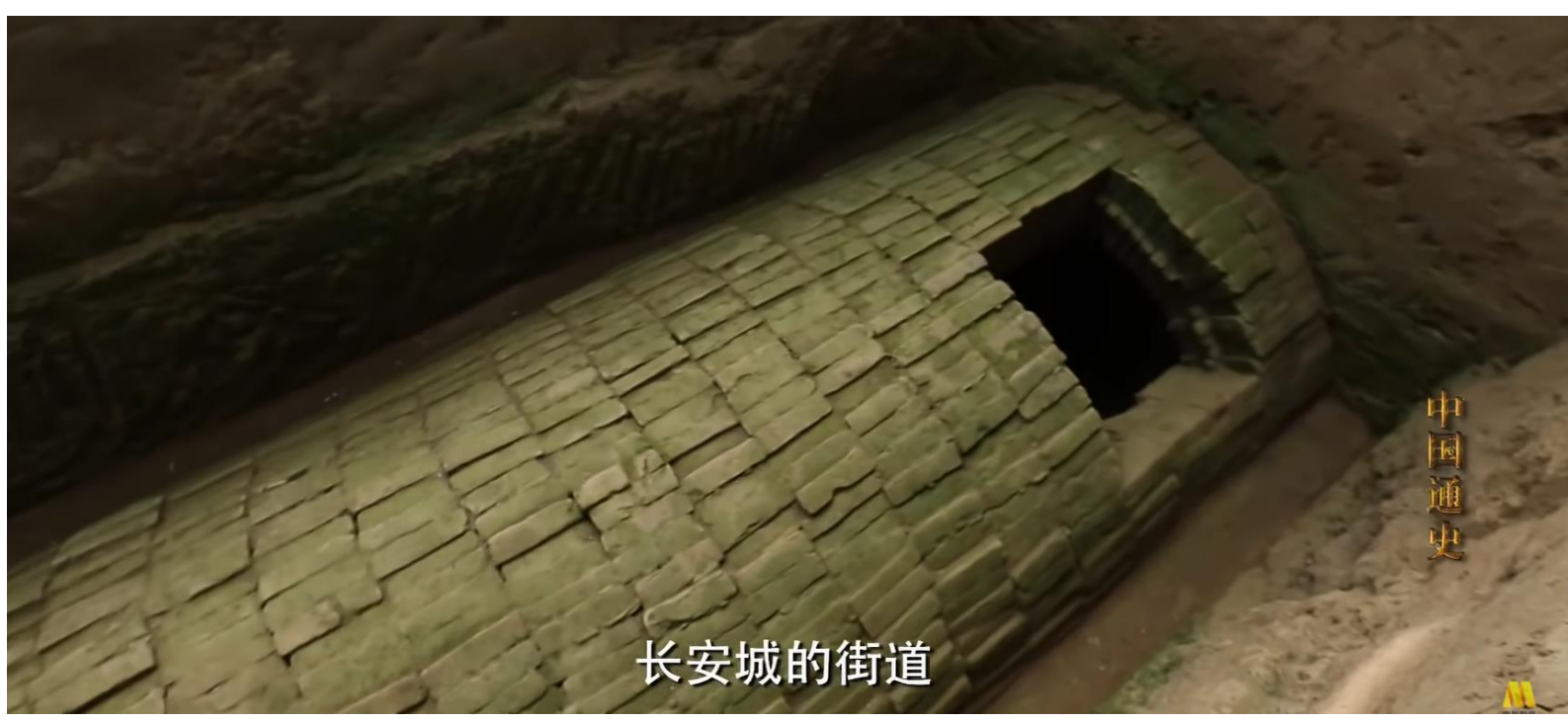

Figure 15. Archaeological excavation of the drainage system in the street of Chang'an City (today's Xi'an, Shanxi Province). Source: screenshot from World Metropolis Chang'an, the 47th episode of the program China History produced by China Movie Official Channel [EB/OL]. (2018, September 20) [cited on 2021, May 2]. https://www.youtube.com/watch?v=XORQzQd_Mj0.

\section{(2) Design of rain and sewage diversion}

The five canals not only supplied water but were used for sewage discharge and flood diversion. Meanwhile, the city laid drainage pipes on both sides of the main streets, Lifang, the East and West Markets, and palace gardens to channel rainwater and domestic sewage to the outside. In World Metropolis Chang'an, the 47th episode of the program China History produced by China Movie Official Channel, Wang Jing, an associate professor from the School of History, Renmin University of China, mentioned that streets in Chang'an descended in height from the middle to both sides, allowing water to flow into ditches and trenches on the roadside. The drainage system also encompassed soakaways and seepage wells. Water in soakaways drained through small ditches into gutters beside the main streets and eventually flowed into the moat.

Both sides of the streets sloped to a certain extent to ensure rainwater emptied into ditches, a design called "slope-forming layer" that is frequently employed nowadays in urban drainage system. Rainwater collected in open conduits, which possessed an inlet every dozens of meters, would flow into covered conduits through those inlets. Water dispersion pits and soakaways were constructed in each street of Lifang and around dwellings, serving as a drainage system for emergency use that helped rainwater from the center of streets and around houses quickly converge into open conduits should any rainstorm arose. Each conduit was connected with the main drainage channel that ultimately drained rainwater into the moat.

Rainwater in the Lifang and streets that were distant from the moat would flow through covered conduits into reservoirs before discharged into nearby ponds and lakes directly or into the moat via the main drainage channel. The largest reservoir of Chang'an was Taiye Pond in the north of the city, in which archaeologists in 2005 discovered three sets of drainage pipes belonging to the Tang Dynasty. Such drainage system still works nowadays. For example, ditches excavated from the west side of Zhuque Street had a trapezoidal cross section 3.3 meters wide at the top and 2.34 meters wide at the bottom, with smooth walls and flat bottom that was covered by sand and silt. Water drained freely through urban pavements thanks to the slope-forming layer and the Poplar Ditch (aka Imperial Ditch). Archaeological discoveries demonstrate that gutters were commonly established on both sides of streets and all of them were above 2.5 meters wide. Ditches in the west side of Zhuque Street (a north-south street at the very 
center of Chang'an that directly led to the Imperial City) had a cross section that was the shape of a trapezoid 3.3 meters wide at the top and 2.34 meters wide at the bottom. Their east and west walls were 2.1 and 1.7 meters deep respectively, both of which leaned 76 degrees and were smooth, containing neither planks nor bricks. Records in Annotations to Ancient and Modern China written by Ma Gao in the Tang Dynasty suggest that "the Imperial ditch in Chang'an is named Poplar Ditch, on the bank of which grew tall poplars. Some people call it Sheep Ditch since it is constructed to block the access of sheep to perimeter walls, while others call it Imperial Ditch given that it allows water sourced from the Zhongnan Mountain to run through the palace."

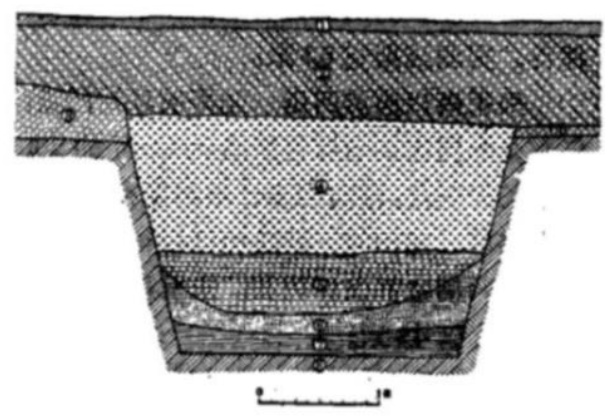

Figure 16. Sectional drawing of the gutter's southern wall in the west side of Zhuque Street. Source: Xi'an excavation task force for Tang Dynasty's cities affiliated to the Institute of Archaeology, Chinese Academy of Sciences, Archaeological Records of the Tang Chang'an City. Archaeology, 1963 (11).

Sewage system of Chang'an consisted of branch pipes buried underground alongside buildings in each Lifang, main pipes and seepage wells. Waste water households drained out came to dedicated brick conduits via those pipes before entering seepage wells eventually. The majority of those pipes were made through firing pottery clay so as to prevent sewage seeping into the ground until it was collectively disposed in seepage wells.

Seepage wells, normally over 3 meters deep, were underground large pits in a rectangular shape with a 1 -foot layer of coarse gravel at the bottom utilized to filter and purify sewage before it leaked into the ground. Some of them employed lime and masonry debris to enhance their filtration and adsorption capabilities. Such wells minimized the pollution of waste water to underground water and was the world's most advanced sewage treatment system at that time, bringing experience to modern effluent disposal.

\section{(3) Digging wells to access domestic water}

In ancient times, the masses accessed domestic water either from wells in the underground or from rivers, canals or lakes at the surface. Surface water dominated since groundwater extraction required a considerable amount of manpower and money, which remained a significant reason why the vicinity of great rivers proved popular for site selection of cities. Extensive Records of the Taiping Era demonstrates "in the street before the Jinggong Temple once stood a huge well commonly known as Octagonal Well. It was in the early years of the Yuanhe Period in the Tang Dynasty that a princess walking by in summer saw the populace drawing water, ordering her maid to fetch some with a silver rimmed bowl. The bowl accidentally fell into the well and appeared in the Wei River over one month later"; "there was an imperial well in the Shanhe Fang. The old claimed that it was low-lying, producing soft water suitable for washing instead of drinking. During the Kaiyuan Period, water was carried into the imperial palace by dozens of camels to supply the Six Palaces (residences of the imperial harem)". The records indicate that underground water was also utilized at that time by digging wells. Wealthy and influential families normally had wells in their own compounds, while the imperial family even requisitioned well water, which, deeply buried in the underground and less exposed to contamination, was of higher quality than 
canal water. In consequence, residents in Chang'an accessed potable water primarily from wells in the ground whereas collecting domestic water principally from canals. Ordinary civilians had access to public wells in each living quarter and temple despite the absence of a well at home. Meanwhile, underground water abounded in Chang'an which was home to a great many rich and influential families, who dug a number of wells.

Textual research conducted by Guo Shengbo, a professor from the Department of History, School of Literature, Jinan University, suggests that wells of the Tang Chang'an that could be confirmed by historical records exceeded 40 , around half of which lay in the southeast of the city.

The drainage system of Chang'an, a complete citywide network consisting of countless gutters, water dispersion ditches, drainage earthen pipes, seepage wells, soakaways, and water supply weirs, was the world's largest and most complex urban drainage system at that time and the crystallization of ancient wisdom.

Notably, it comprised two separate systems respectively for rainwater and sewage drainage, the diversion of which proves unattainable even in some of current big cities but was already achieved in the Tang Chang'an City. It remains an advanced concept and technology, providing valuable experience for the drainage of modern cities.

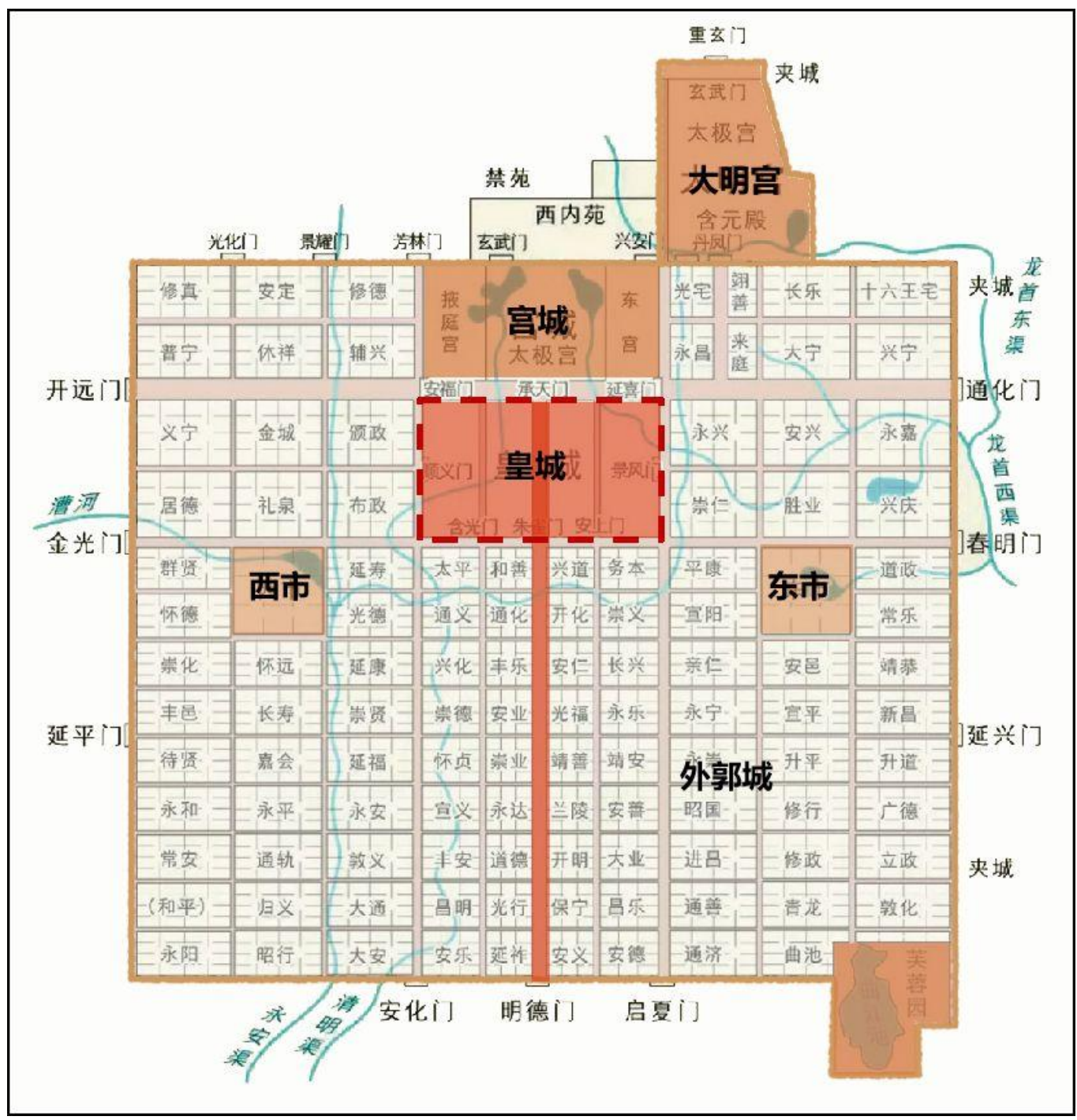

Figure 17. Ground plan of the Tang Chang'an. Source: Branch of Historical Cities, Research Institute of Xi'an City Planning \& Design. 


\subsubsection{Management of the Lifang system and imposition of a curfew}

Chang'an, capital of the Tang Dynasty that was the then most developed city of the world, already performed a variety of urban functions. The early Tang Dynasty strictly divided its urban spaces into the Palace City, the Imperial City, and the Outer City, with blocks resembling squares on a chessboard, each of which was called a "Li" or "Fang". The Outer City was divided by crisscrossing streets into 108 Lifang and the East and West Markets. Each Lifang, which was surrounded by towering perimeter walls, appointed Lizheng (official at the grassroots level) to open and close the gate in line with the morning and evening drumrolls. A night curfew was imposed in the charge of specially-assigned officials, wherefore anyone breaking it would be questioned by the night patrol. In World Metropolis Chang'an, the 47th episode of the program China History produced by China Movie Official Channel, Qi Dongfang, a professor from the School of Archaeology and Museology, Peking University, stated that the Tang Chang'an under such system was characterized by military control.

Governance approaches composed of the Lifang system and curfew imposed strict restrictions on the space and time of economic activities and limits on the interaction and contact among people. Lifang system partly helped prevent and control epidemic disease, restore the lives of people in infectious areas and minimize property loss.

\subsubsection{Improving urban living environment through tree planting}

Landscaping, which is closely related to health, gained special attention from the rulers of the Tang Dynasty. Tree planting and greening work in Chang'an was in the charge of Metropolitan Governor and carried out by the Left and Right Street Supervisors through mobilizing the entire people to participate, with costs covered by the government. Integrated planning was made to boost the street greening of Chang'an by the court that, in particular, explicitly stipulated what tree species to plant along streets. Zhuque Street, the central avenue giving direct access to Zhuque Gate and Chengtian Gate, remained a route which the emperor, officials and foreign envoys who came to pay tribute would never bypass during their tour. It was solely lined with Sophora Japonica, hence also called "Street of Sophora Japonica" or "Ya of Sophora Japonica" (Ya literally meaning administrative office and/or residence of a local bureaucrat). Elms grew along the alleys and lanes of Lifang, whereas poplars and willows were planted on ditch banks and riverside, particularly in the south street of Jinggong Fang.

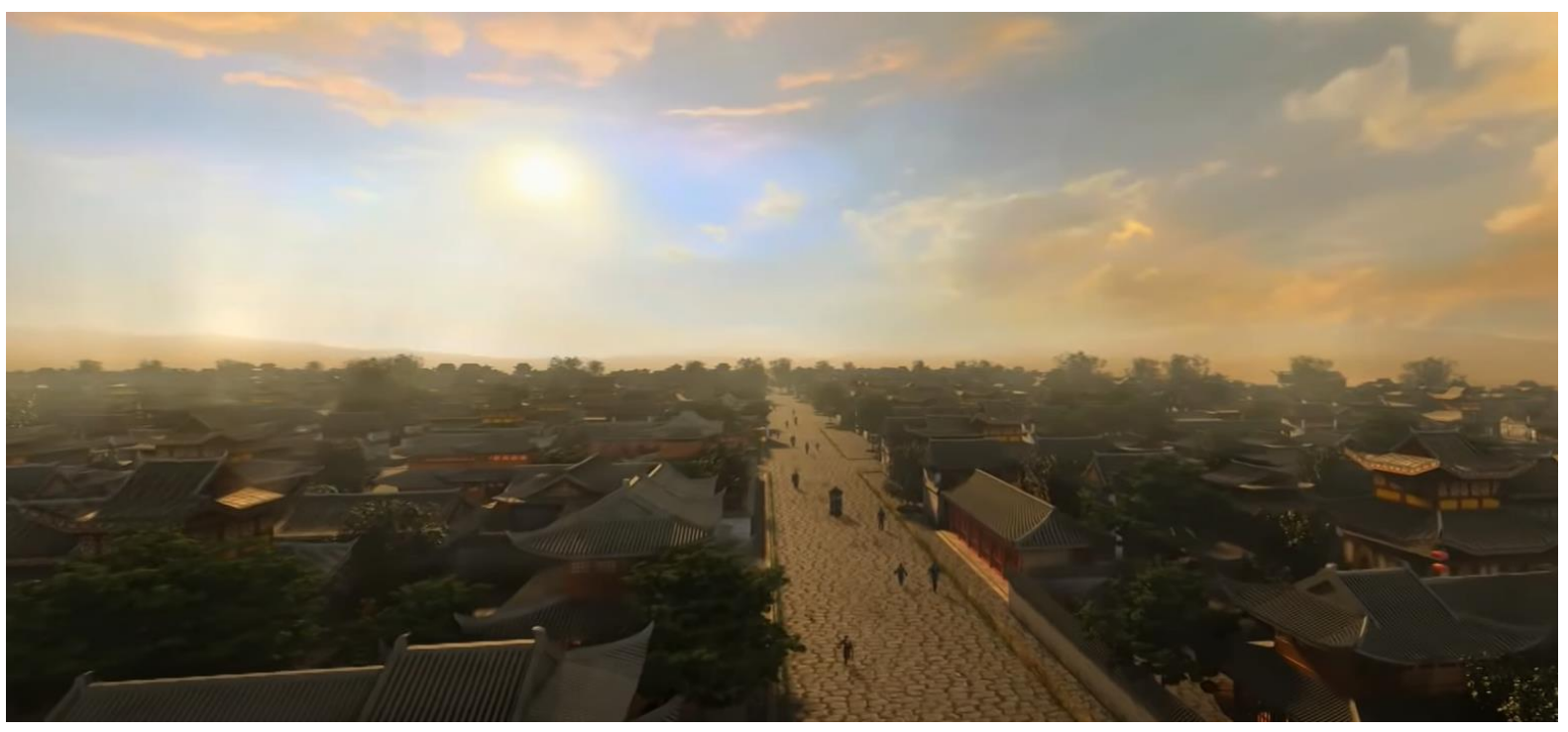

Figure 18. Reproduced image of Zhuque Street in Chang'an City. Source: screenshot from World Metropolis Chang'an, the 47th episode of the program China History produced by China Movie Official 


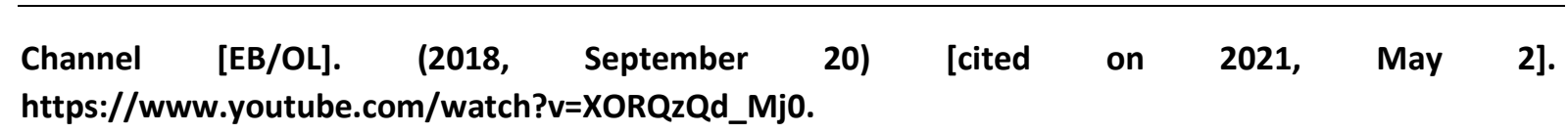

The Tang Dynasty government also attached great importance to the flora in the streets, enacting a series of effective measures to improve conservation and management. Director of the Bureau of Forestry and Crafts, was appointed to be responsible for urban greening and road management apart from supervising mountain forests, rivers and gardens, especially flowers and trees in the streets. It was stipulated that, without prior permission, neither officials nor civilians in the city were allowed to plant trees on either side of the streets. The Western Inner Garden, the Eastern Inner Garden and the Forbidden Garden, three palace gardens adjoining Chang'an City, lay in a lush green area where forest flourished, pools and ponds converged, palace gardens totaled dozens, and exotic flowers and rare trees abounded. Additionally, Qujiang Pond and Apricot Orchard situated outside Chang'an City were popular scenic spots with uniquely designed garden landscapes that looked picturesque and distinctive. The Qujiang Pond, dominated by the scenery of a large deep lake containing green water, along the bank of which was densely planted with willows, apricots and flowers, boasted irregularly yet exquisitely placed pavilions and drew a steady stream of visitors through every season.

Records of the street greening in Chang'an are available in Research on the Urban Blocks of the Tang Dynasty's Two Capitals written by Xu Song of the Qing Dynasty, the 2nd volume of Records of Chang'an City, the poem Willows along the Imperial Ditch by Du Xunhe, and some verse composed by Wang Wei, Bai Juyi and Wei Yingwu. Among historical materials recording the management standard for greening and events concerning fruit tree planting in Chang'an are the edict issued by Emperor Daizong of Tang in 773 AD, the two chapters of Streets and Alleys, and Roads in Tang Huiyao (literally meaning Institutional History of Tang), Ode after Inspecting Fruit Tree Planting on the Roads of the Two Capitals under Emperor's Order and Returning Chang'an by Zheng Shen, and Volume 9 of the Old Book of Tang. Garden landscapes in Chang'an could be found in Anecdotes about the Kaiyuan and Tianbao Periods written by Wang Renyu. Specific descriptions are presented in Table 2.

Table 2. Historical records of landscaping in the Tang Dynasty. Source: compiled by the author based on historical materials.

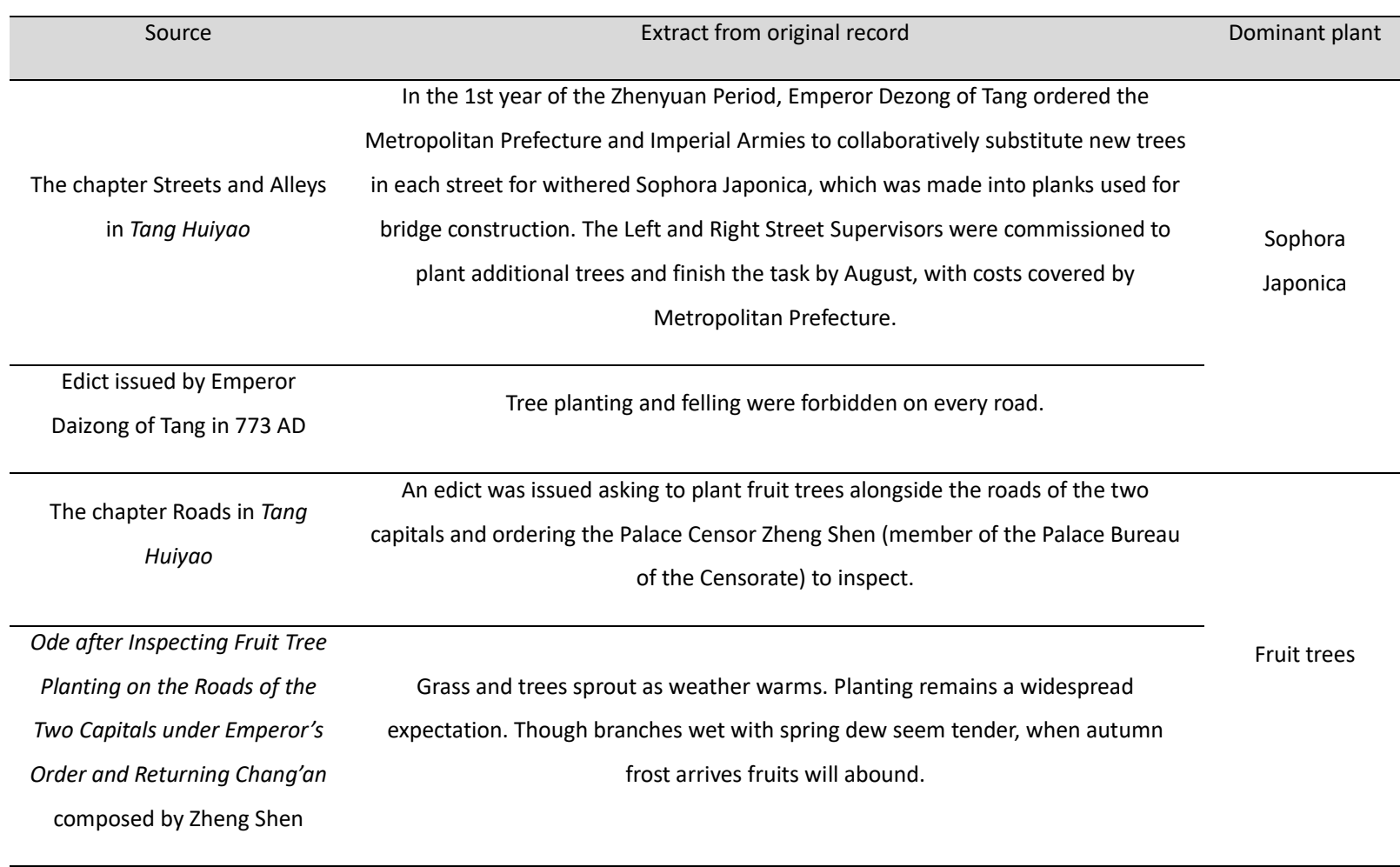




\begin{tabular}{|c|c|c|}
\hline Source & Extract from original record & Dominant plant \\
\hline $\begin{array}{l}\text { Volume } 9 \text { in the Old Book of } \\
\qquad \text { Tang }\end{array}$ & $\begin{array}{l}\text { In January, the spring of the 28th year (during the reign of Emperor Xuanzong), fruit } \\
\text { trees were planted along the roads of the two capitals and in gardens of Chang'an } \\
\text { City. }\end{array}$ & \\
\hline Wang Wei & $\begin{array}{l}\text { When I overlook the streets in Chang'an, roads extend in all directions, on which } \\
\text { green Sophora Japonica differs in height and carriages and horses stream. }\end{array}$ & $\begin{array}{l}\text { Sophora } \\
\text { Japonica }\end{array}$ \\
\hline Wei Yingwu & $\begin{array}{l}\text { Weeping willows growing in the streets of Chang'an nestle around the mansion of } \\
\text { dignitaries. }\end{array}$ & Weeping willows \\
\hline $\begin{array}{l}\text { Willows along the Imperial } \\
\text { Ditch by Du Xunhe }\end{array}$ & $\begin{array}{l}\text { Spring arrives at the Imperial Ditch, beside which willows look green and fresh. } \\
\text { Cautiously passing through the water in the way and gently flicking the branches } \\
\text { overhead, there enters a person in the morning. }\end{array}$ & Willows \\
\hline $\begin{array}{l}\text { Volume } 2 \text { in Records of } \\
\text { Chang'an City }\end{array}$ & $\begin{array}{l}\text { Wu Cou once planted Sophora Japonica in the imperial streets in the 14th of } \\
\text { Zhenyuan Period. }\end{array}$ & $\begin{array}{l}\text { Sophora } \\
\text { Japonica }\end{array}$ \\
\hline $\begin{array}{l}\text { Anecdotes about the Kaiyuan } \\
\text { and Tianbao Periods written } \\
\text { by Wang Renyu }\end{array}$ & $\begin{array}{l}\text { Sightseeing is popular in Chang'an when spring comes, with visitors thronging the } \\
\text { gardens planted with trees. }\end{array}$ & $\begin{array}{l}\text { Ornamental } \\
\text { trees }\end{array}$ \\
\hline Research on the Urban Blocks & & \\
\hline of the Tang Dynasty's Two & The broad Chengtianmen Street is lined with Sophora Japonica, making refreshing & Sophora \\
\hline $\begin{array}{l}\text { Capitals written by Xu Song of } \\
\text { Qing }\end{array}$ & shade available. & Japonica \\
\hline
\end{tabular}

Textual research suggests that Sophora Japonica growing in the then Chang'an City, namely Chinese scholar tree that is currently the city tree of Xi'an, has a history of over 1,300 years. Chinese scholar tree has terminal panicles with creamy white corollas. Its flower, cold in nature with bitter taste, has the function of clearing heat and cooling blood, purging fire from liver, and stopping bleeding. The flower buds can be used for dye, pulp for medicine, and the black kidney-shaped seeds for fodder. It proves a fine species both for the greening of urban streets and for producing timber thanks to its strong resistance to soot and harmful gases, such as sulfur dioxide, chlorine, and hydrogen chloride. Scientific research indicates that extensive tree and flower coverage in a city can enhance its natural ecological system, since plants help regulate microclimate, improve the environment, reduce the greenhouse effect, abate noise, control dust and sterilize by absorbing harmful gases in the air and releasing oxygen.

\subsubsection{The medical ideology that "prevention matters more than cure" proposed by Sun}

\section{Simiao, a physician of the Tang Dynasty}

Medical progress in the Tang Dynasty was greatly attributed to the historical background. In that dynasty, social production boomed unprecedentedly, economy thrived, territory was unified, ethnic relations remained harmonious, and domestic and foreign culture was diverse, which provided favorable material conditions that helped assimilate foreign medical skills, compile and edit ancient medical books, and exchange and study experience of epidemic control. Moreover, the printing techniques, agricultural technologies, and overall medical literacy of doctors all improved, which laid a solid foundation and provided diagnostic and treatment experience for the revision and writing of quality medical books, 
popularization of prescriptions and medicines, identification of the toxicity and medicinal properties of herbal preparations, and the administration of medication by medical practitioners traveling around.

Sun Simiao (581-682 AD), titled as China's King of Medicine, was the first person in Chinese history that proposed "prevention matters more than cure". In particular, he maintained that epidemic diseases were entirely possible to prevent, though beyond possibility to eliminate. Those essential prevention methods he put forward still retain value until nowadays. He mentioned in Qian Jin Yao Fang (Prescriptions Worth a Thousand Pieces of Gold) various preventive measures to improve hygiene, including fumigation (i.e. air disinfection), putting herbs into wells (sterilizing well water) and avoiding eating uncooked food (sterilizing food by cooking). This book repeatedly advocates preventing severe and widespread epidemics through fumigation. "Drinking medical liquor helps prevent the spread of epidemic diseases from one person to his family or from one family to the neighborhood within the range of 500 meters." "People should avoid eating uncooked vegetables and rice, as well as stale and smelly food." "Everyone should develop the habit of not spitting on the ground." "Rinsing your mouth several times is necessary after eating." These claims manifest that he valued personal hygiene and epidemic prevention.

\subsubsection{Epidemic control concept of "integrating three religions' ideas" led by the Tang} rulers

The Han Dynasty abandoned all other schools of thought and followed exclusively the teachings of Confucianism, which became a dominant philosophy in the Tang Dynasty. A series of policies favorable to people's livelihood were enacted by rulers of the Tang Dynasty primarily based on Confucianism, covering delivery of medical services, suppression of infections and tax break. The government also promulgated laws stipulating that patients must seek medical treatment from the local area instead of any other district to prevent cross-infection. On the other hand, Taoist immortal pills, spells and rites were copied and absorbed by Buddhist rituals and government-led medical services. The Tang rulers not only disseminated Buddhist medical culture but adopted Taoist services exemplified by its medicine and teachings, which supported anti-epidemic activities by gathering strong efforts and diversified, effective resources for medical assistance.

A plague arising in the Tang Dynasty would directly impact social order and the workforce, or even worse, engender social panic, massive loss of agricultural population and political unrest with charlatans emerging in large numbers. Therefore, each emperor issued several imperial edicts on epidemic control and pacification. For instance, Emperor Daizong enacted the Edict of Relieving People's Hardship proposing relief measures to address the "severe epidemic disease spreading in Hangzhou and Yuezhou", while Emperor Wenzong issued the Decree of Relieving and Comforting People in All States to defuse the situation. What also merited attention was that the Tang rulers repeatedly ordered local states to curb the spread of epidemic diseases and stem the misdiagnosis of witch doctors through transcribing prescriptions. For instance, Shennong Bencao Jing (Shennong's Materia Medica Classic) was transcribed under the order of Emperor Xuanzong before Guangji Fang (Prescriptions for Extensive Remedy) was introduced and promoted, a tradition followed by most of later emperors. Fighting epidemics and popularizing prescriptions under the leadership of the ruler contributed to long-term and effective control of the diseases.

\section{Reflections on Urban Epidemic Prevention and Control during the Post- Epidemic Era}

Currently, China has put the COVID-19 well under control and resumed its production, during which reflections are necessary on how to prevent and control urban epidemic during "the post-epidemic era". Epidemic prevention and control in the Tang Chang'an affords us lessons from the aspects of urban 
construction (including site selection, and water supply and drainage), urban management (Lifang system) and education of civilians (medical ideology). Firstly, the huge urban population must have access to sufficient medical facilities, with water supply well protected through diversion, while the present residential blocks, each of which resembles "Lifang" in the Tang Dynasty, need to improve their prevention and treatment system that is graded according to severity. Furthermore, energy of urban managers remains limited, and it is necessary to promote public health measures to educate individuals and communities.

Interdisciplinary collaboration between urban planning and public health requires to be strengthened in the future so as to promote public health by utilizing spatial governance.

\section{Acknowledgements}

Research on the course of "History of Urban and Architectural Development" for PhD students in the 2020-2021 academic year of Macau University of Science and Technology.

\section{References}

Rosenberg, M. T. (2008, June 29). Largest Cities Through History.

Morris, I. (2010, October). Social Development. Stanford University. This contains supporting materials for the following book: (b) Morris, I. (2010). Why the West rules-for Now: the Patterns of History, and What They Reveal about the Future. New York: Farrar, Straus and Giroux. ISBN 978-0-374-29002-3.

Ebrey, P. B. (2008). East Asia: A Cultural, Social, and Political History (p. 78).Wadsworth Publishing. ISBN 978-0547005348.

Morris, I. (2013). The Measure of Civilization: How Social Development Decides the Fate of Nations. Princeton University Press. ISBN 978-0691155685.

Lockard, C. A. (2010). Societies, Networks, and Transitions, Volume B: From 600 to 1750 (p. 275). Wadsworth Publishing. ISBN 978-1439085400.

Benn, C. (2004). China's Golden Age: Everyday Life in the Tang Dynasty (p. 46). Oxford University Press. ISBN 978-0195176650.

Guntern, G. (2010). The Spirit of Creativity: Basic Mechanisms of Creative Achievements (p. 419). University Press of America. ISBN 978-0761850519.

Zhen, Q. S. (2012). Research on the Prevention and Cure of Epidemic Disasters in the Tang Dynasty [MA thesis]. Minzu University of China.

Wu, X. L. (2021). Geographical Distribution of Cemeteries for Residents in Anren Fang in the Tang Chang'an City Recorded in Epigraphs. Wenbo, 01, 78-87. doi:CNKI:SUN:WEBO-0.2021-01-011.

Feng, X. D. (2020). Water Resources and its Utilization in Chang' an City of the Tang Dynasty. Tangdu Journal, 2020, 36 (4), 27-33. doi:CNKI:SUN:TDXK.0.2020-04-009.

Wang, Y. J. (2020). Discussion on the Wells and Public Life in Chang'an City of the Tang Dynasty [MA thesis]. Minzu University of China.

Wang, Y. J. (2019). Spaces for Public Activities in Fang in Chang'an City of Tang. Popular Archaeology, 12, 38-43. doi:CNKI:SUN:KGDZ.0.2019-12-013.

Zheng, X. D. (2019). Overview of Greening in Chang'an City of Tang. Yellow River Yellow Earth Yellow Race, 2019 (02), 51-53, 64. doi:CNKI:SUN:HHHR.0.2019-02-019. 
Xing, F. L., Zhang, J. Y., \& Miao, Y. F. (2018). Archaeological Interpretation of the Cemetery in Daju'an Village, Gaoyangyuan, the Southern Suburb of Chang'an City of Tang. Popular Archaeology, 2018 (10), 35- 45. doi:CNKI:SUN:KGDZ.0.2018-10-012.

Guo, P. J., Liu, H. L., Yang, S. P., Xiao, J., \& Chen, X. (2018). Environmental Construction of Chang'an City in the Tang Dynasty and Its Enlightenment to Today. Journal of Hainan Normal University (Natural Science), 2018, 31 (02), 226-231. doi:CNKI:SUN:HNXZ.0.2018-02-017.

Liu, H. (2017).Research on the Temporal and Spatial Background and Content of the Curfew System in Chang'an City of Tang. The Journal of Humanities, 2017 (04), 108-113. doi:10.15895/j.cnki.rwzz.2017.04.014.

Water System Construction of Chang'an in the Sui and Tang Dynasties. (2017).Architectural Knowledge, 2017, 37 (06), 28-37. doi:CNKI:SUN:JZZS.0.2017-06-006.

Yang, Y. J. (2016). Discussion on the Public Character of Gardens in Chang'an City of Tang based on "Passing a Cup in the Qujiang Pond to Drink". Huazhong Architecture, 2016, 34 (07), 143-145. doi:10.13942/j.cnki.hzjz.2016.07.033.

World Metropolis Chang'an, the 47th episode of China History produced by China Movie Official Channel [EB/OL].Available at: https://www.youtube.com/watch?v=XORQzQd_MjO(Accessed: 2 May 2021) 